KARE - Uluslararası Karşılaştırmalı Edebiyat, Tarih ve Düşünce Dergisi

KARE - International Comparative Journal of Literature, History and Philosophy

Başlık/ Title: Kore Kültüründe 12 Hayvan Sembolleri ve Anlamları / Symbols and Meanings of 12 Animals in Korean Culture

Yazar/ Author

ORCID ID

Jung Hye LEE

$0000-0002-8507-461 X$

Bu makaleye atıf için: Jung Hye Lee, Kore Kültüründe 12 Hayvan Sembolleri ve Anlamları, KARE, no. 9 (2020): 198-232.

To cite this article: Jung Hye Lee, Kore Kültüründe 12 Hayvan Sembolleri ve Anlamları, KARE, no. 9 (2020): 198-232.

Makale Türü / Type of Article: Araştırma Makalesi / Research Article

Yayın Geliş Tarihi / Submission Date: 27.01.2020

Yayına Kabul Tarihi / Acceptance Date: 30.06 .2020

Yayın Tarihi / Date Published: 30.06.2020

Web Sitesi: https://karedergi.erciyes.edu.tr/

Makale göndermek için / Submit an Article: http://dergipark.gov.tr/kare

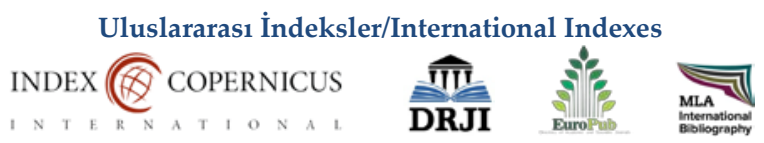

Index Copernicus: Indexed in the ICI Journal Master List 2018 Kabul Tarihi /Acceptance

Date: 11 Dec 2019

MLA International Bibliography: Kabul Tarihi /Acceptance Date: 28 Oct 2019

DRJI Directory of Research Journals Indexing: Kabul Tarihi /Acceptance Date: 14 Oct 2019

EuroPub Database: Kabul Tarihi /Acceptance Date: 26 Nov 2019

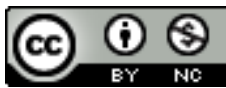

This work is licensed under a Creative Commons AttributionNonCommercial 4.0 International License. 


\title{
Yazar: Jung Hye LEE*
}

\section{Kore Kültüründe 12 Hayvan Sembolleri ve Anlamlar1 ${ }^{1}$}

Özet: Tarih boyunca hemen hemen tüm toplumlarda görülebildiği gibi Kore'de eski dönem kaya ve mağara resimlerinde görülen hayvan figürleri; çanak, çömlek ve heykeller, mezar höyükleri, efsane, masal, atasözü, deyim, edebiyat eserleri ve halk inançları gibi pek çok alanda ortaya çıkmaktadır. Burada yer alan hayvan simgeleri çeşitli anlamlar içererek Korelilerinin halk inançlarını ve düşüncelerini yansıtmaktadır. Dolayısıyla hayvan sembolleri Kore kültüründe önemli yer tutmaktadır. Ayrıca Korelilerin doğum yıllarını belirten 12 hayvan, Koreliler için özel bir anlam taşır. Kore'de 12 hayvan takviminde yer alan hayvanlar; masal, atasözleri ya da edebî eserlerde çeşitli şekillerde boy göstermektedir. Bu nedenle Korelilerin hayvanlara yükledikleri anlamlar, Kore kültürü ve Korelilerin duygularını anlamamızda önemli bir araç olmaktadır. Ayrıca Kore halkının hayvanlara yüklediği anlamlar, Kore halk inanışlarını, efsanelerini ve edebi eserlerini anlama konusunda da önemlidir.

Bu nedenle bu çalışmanın amacı, Korelilerin düşünceleri ve günlük hayatlarında önemli bir unsur olarak yer edinmiş olan 12 hayvanlı takvimi merkez alarak Kore'deki hayvan sembolleri ve anlamlarını incelemektir. Bu inceleme, iki bölümden oluşmaktadır. Öncelikle Kore'nin çeşitli edebiyat, sanat, dil vb. alanlarında yerleşmiş olan hayvan motifi kullanımları ve bu motiflerin sembolik anlamları genel olarak gözden geçirilecektir. İkinci olarak, Korelilerin günlük yaşamında etkili olan 12 hayvanlı takvimi üzerinde durulacaktır.

Anahtar Kelimeler: Hayvan sembolleri, hayvan anlamları, Kore kültürü, halk inanışı, 12 hayvanlı takvimi.

\section{Symbols and Meanings of 12 Animals in Korean Culture}

\begin{abstract}
The Animal figures seen on ancient rocks and cave paintings in Korea have also been widely used in many fields such as pottery, sculptures and statues, burial mounds, legends, fairy tales, proverbs, idioms, literature and folk beliefs. The animal symbols mentioned in the article have various meanings and reflect the beliefs and thoughts of the Korean people and folklore. These animal symbols and representations therefore have a significant place in the Korean culture. The 12 animals signs assigned to Korean birth years, in particular, have a special significance for Koreans. The Animals in the Korea's 12 Animal Calendars are also seen in fairy tales, proverbs or literary works in various and different forms. Therefore, the meanings that the Koreans place on animals plays an important role in understanding and interpreting the Korean culture and emotions. Furthermore, the meanings given to animals by the Korean people constitute an important background in understanding the Korean folk beliefs, legends and literary works.

Therefore, the purpose of this study is to examine the animal symbols and their meanings in Korea by focusing on the 12 animal calendars which have an important place in and influence on the Korean thoughts and daily life. This review consists of two parts. The former part aims examine the use of animal motifs and their symbolic meanings that have been widely used in
\end{abstract}

\footnotetext{
* Öğr. Gör. Dr., Erciyes Üniversitesi Edebiyat Fakültesi Kore Dili ve Edebiyatı Böl. leeistanbul@gmail.com, Orcid No: 0000 -0002 -8507-461X

${ }^{1}$ This work was supported by the Core University Program for Korean Studies through the Ministry of Education of the Republic of Korea and Korean Studies Promotion Service of the Academy of Korean Studies(AKS-2019-OLU-2250002)
} 
Korea's literature, art, language and etc. while the second part focuses on the calendar of 12 animals that have a significant influence on the daily lives of Koreans.

Keywords: Animal symbol, animal meaning, Korean culture, folklore belief, 12 animal calendars.

\section{Giriş}

Hayvanlar, tarih öncesi zamanların bir sembolü olarak büyülü inançların muhatapları, mitolojide mitleri temsil eden kutsal varlıklar ve totemlerin nesnesi olarak ifade edilmektedir. ${ }^{2}$ Dolayısıyla insanlık tarihi ile bitmeyen bir ilişki oluşturmaktadır. Birçok hayvan, insanlardan farklı olarak sınırsız hareket alanına sahiptir. Bundan dolayı bir dünya görüşü ile diğer bir dünya görüşü arasında bağ kurabilmekte ve tanrıyla insanın anlaşabilmesini sağlayan bir araç olarak bilinmektedir. ${ }^{3}$

Kore'de kuruluş efsanesi olan Dangun Efsanesi(단군신화)'nden itibaren totem inancı vardır. Kore ulusunun atası Dangun'un da, insan ve ayının birleşmesinden olduğuna inanılarak hayvanlar kutsal olarak görülmüştür. ${ }^{4}$ Bundan sonra hayvanlar petroglifler, mezar duvarı resimleri, towoo (토우) ${ }^{5}$, çömlekler, altın tütsü kabı, mezarlık hayvan heykeli, halk resmi gibi çeşitli alanda şekillendirilmiştir. Bunların dışında da masal, halk inanışı, mevsimsel gelenekler, halk oyunları, atasözleri, çocuğa yorumlanan rüyalar, feng şui teorisi (풍수지리설) ${ }^{6}$, edebi eserler, ayrıca günlük hayatta kullanılan eşyalar, zanaat eserleri ve giysilerde de hayvanlar kişileştirilerek ya da betimlenerek

2 김태영, 동물의 원형적 상징과 조형의식 -원시 신앙과 관련된 동물을 중심으로-, 석사논문, 국민대학교, 2005, 7.

3 장현주-하종경, “조선시대 직물에 나타난 동물문양의 유형과 특성”, 복식, 55(5), $(2005,8)$, 한국복식학회, 66 .

4 일연, 삼국유사, 기이 제1권, "고조선", (김원중 옮김), 민음사, s. 20. 삼국유사(Samkukyusa), Üç Krallık Dönemi(삼국시대, m. ö. 1.yüzyıl m. s. 7. yüzyıl)'ni kapsayan tarih eseridir. Özellikle Kore kuruluşu efsanesi olan Dangun efsanesini anlatan ilk tarihi kitap olarak önem taşımaktadır; 한국민족문화대백과, "삼국유사”, (Erişim tarihi, 06 Mayıs 2020),

https://terms.naver.com/entry.nhn?docId=2457207\&cid=46669\&categoryId=46669

5 Towoo, kilden yapılan insan veya hayvan figürlü heykeldir. Bu heykeller, yakarış ve tapınmanın nesnesi olup aynı zamanda mezara konan aksesuarlardır. Mezar içine konan Towoo' ların merhuma hizmet edeceği düşüncesi vardır; 허은아, 신라의 동물형 토우에 관한 연구, 석사논문, 전남대학교, 1993, 6 .

${ }^{6}$ Toprağın şekline ve hangi yöne baktığına bağlı olarak insan hayatında iyi ya da kötü şeylerin olabileceğini açılayan bir teoridir; 두산백과, "풍수지리설", https://terms.naver.com/entry.nhn?docId=1159140\&cid=40942\&categoryId=31445， (Giriş tarihi, 06 Mayis 2020) 
kullanıla gelmiştir. ${ }^{7} \mathrm{Bu}$ yüzden Kore'de hayvan motifleri sözlü edebiyat, halk inancı ve yaşam kültürünün büyük bir kısmına yayılarak Kore kültürünü oluşturmaktadır.

Hayvan motifleri, o döneme ait insanların ifade etmeyi amaçladığı anlam ve fikirleri içermektedir. Hayvanların sembolik anlamları genel olarak ortak bir görüş taşır. Ancak bazen o an ki ihtiyaç ve dönemsel anlamda aralarındaki karşılıklı ilişki nedeniyle karmaşık, çok yönlü ve bazen oldukça farklı bir sembol olarak da ortaya çıkmaktadır. ${ }^{8}$ Bir de her ülkenin ve her ulusun sevdiği hayvanlar farklıdır. Sevilen hayvanlar aynı olsa da onlara yüklenen kültürel anlamlar ve onlarla ilgili duyulan hisler faklıdır. Ayrıca hayvanlar, aynı kültürün etki ettiği yerlerde de görüldügü mekân, zaman ya da gören kişinin bakış açısına göre çeşitli sembol ve anlamlar taşır. ${ }^{9} \mathrm{Bu}$ açıdan bakıldığında şimdiki Kore kültüründe görülen hayvan sembollerinin Korelilerin uzun süre boyunca hayvanlar hakkındaki anlayış ve hayal gücünün çerçevesinde oluştuğu anlaşılmaktadır. Dolayısıyla hayvan sembolleri, Korelilerin hayal gücü ve düşünce yapısının birleşmesinden ortaya çıkan öz olarak görülmektedir. ${ }^{10}$

Ayrıca Korelilerin doğum yıllarını belirten 12 hayvan sembolü, Koreliler için özel bir anlam taşımaktadır. Şibici(12 hayvanlı takvim)'in ortaya çıkması Çin'in Han hanedanlığ döneminde başlamıştır ${ }^{11}$ ve 12 hayvan, 12 doğum burcunu simgeleyen hayvanlar olarak yerini almıştır. '십 이지(Şibici)' kelimesi

\footnotetext{
7 장현주-하종경, “조선시대 직물에 나타난 동물문양”, 66.

8 김태영, 동물의 원형적 상징과 조형의식, s. 7

9 장현주-하종경, “조선시대 직물에 나타난 동물문양”, 66.

10 김종대, “動物을 통해본 民俗象徵과 意味에 대한 한 考察”, 민속학연구, 8(2001), 국립민속박물관, 158.

${ }^{11}$ Türkiye' de bazı bilim insanları, esasen eski zamanlarda kullanılan Sal-i Türkan(Türk yılı) adlı 12 hayvanlı Türk takviminin Çinlilerden daha önce kullanıldığı iddiasında bulunur. Türklerin Kuzey-doğu Asya uluslarından devralarak Göktürk döneminde güneş yılı esasına dayanan 12 hayvanlı takvimi kullandığı için Çin kökeni olarak bilinen 12 hayvanlı takvimin aslında Türklerden Çinlilere geçtiği söylenir. Buna karşıt fikirler de mevcut olduğundan 12 hayvanlı takvimin menşei halen Türk bilim alanında sürdürülen bir tartışma konusudur; Ufuk Tavkul, "Kültürel Etkileşim Açısında On İki Hayvanlı Türk Takviminin Yayılışı”, Modern Türklük Araştırmaları Dergisi, Cilt 4, sayı 1(Mart 2007), Ankara Üniversitesi, s.27; Yavuz Unat, “İslâm’da ve Türklerde Zaman ve Takvim”, Türk Dünyası, Nevruz Ansiklopedisi, (ed. Öcal Oğuz),Atatürk Kültür Merkezi Başkanlığı Yayınları, Ankara 2004, s. 17; İlhami Durmuş, “Eski Türklerde Zaman ve Takvimler", https:/www.gunaz.tv/az/xeberler/arxiv/eski-turklerde-zaman-ve-takvimlerprof-dr-ilhami-durmus-49577, (giriş tarihi, 07 Mayıs 2020); Nergis Biray, “ 12 Hayvanlı Türk Takvimi- Zaman ve İnsana Hükmetmek-, A.Ü. Türkiyat Araştırmaları Enstitüsü Dergisi, Prof. Dr. Hüseyin AYAN Özel Sayısı, Sayı 39, Erzurum 2009, s. 672; Mustafa Balc1, “Bilinmeyen Bir 12 Hayvanlı Takvim Risalesi: Takvim-i Tatar Ma'a-acem”, Türkbilgi, Sayı 20 (2010), s. 87, 89.
} 
Koreliler için 12 hayvan takvimi olarak bilinir ve bu takvim insanların doğum yılı hayvanını temsil etmektedir. Bu yüzden Koreliler 12 burcu (12 띠) 12 hayvan (12 동물) olarak bilmektedirler. Kore'de 12 hayvanlı takviminde yer alan hayvanlar her türlü masallarda ya da edebî eserlerde çeşitli şekillerde görülmektedir. Ayrıca Kore ulusunun his ve düşüncelerini aktaran atasözü ve deyimlerde kullanım örnekleri oldukça sık göze çarpmaktadır. Bu yüzden Korelilerin hayvanlarla ilgili algıları ve kullanımları onların kültür ve hislerini anlamamızda önemli bir araç olmaktadır. Bir de Kore halkının hayvanlarla ilgili düşünceleri, Kore halk inanışlarını, efsanelerini ve edebi eserlerini anlama konusunda da önemli bir unsur olmaktadır.

Bu çalışmanın amacı, Kore kültüründe ve günlük hayatlarında önemli bir unsur olarak yer edinmiş olan 12 hayvan takvimini merkez alarak Kore'deki hayvan sembolleri ve anlamlarını incelemektir. Bu metin, iki bölümden oluşmaktadır. Öncelikle, Kore'nin çeşitli edebiyat, sanat, dil vb. alanlarında yerleşmiş olan hayvan motifi kullanımları ve sembolik anlamları genel olarak gözden geçirilecektir. İkinci ise, Korelilerin günlük yaşamlarının içinde yer edinmiş olan 12 hayvanlı takvim sembolü ve çeşitli kullanım alanlarına değinilecektir.

Bu çalışmanın, Kore kültürü ve edebi eserlerini anlamada, ayrıca bu alanda yapılan araştırmalarda kaynak olarak yarar sağlayacağ düşünülmektedir. Ayrıca bu makalenin, Kore kültürü ile başka ulusların kültürleri üzerine yapılacak karşılaştırmalı çalışmalarda da yardımcı bir kaynak olacağı düşünülmektedir.

\section{Kore'de Hayvan Motiflerinin Kullanımı ve Simgeleri}

Kore'de eski dönemlerden itibaren kaya ve mağaradaki resimlerde görünen hayvan figürleri; heykeller, mezar höyükleri, efsane, masal, atasözü, deyim, edebiyat, halk inançları ve çanak, çömlek, vazo hatta kıyafetlerde dahil olmak üzere günlük yaşam eşyaları gibi pek çok alanda ortaya çıkmaktadır. Burada yer alan hayvan simgeleri çeşitli anlamlar içererek Korelilerinin halk inançlarını ve düşüncelerini yansıtmaktadır.

Kore'nin kuruluş efsanesinde çeşitli hayvan simgeleri ortaya çıkmaktadır. Kuruluş efsanelerinin kahramanları ve içerikleri farklı olmasına rağmen hayvan simgeleri benzerlik göstermektedir. Bunun nedeni, efsanenin oluşumundan önce evrensel bir inanç olduğu ve bu inançta hayvan simgelerinin önemli unsurlar olduğu anlaşılmaktadır. ${ }^{12}$ Dangun

12 이현주, 신라의 건국신화와 동물 상징, 석사논문, 성균관대학교, 2004, 2. 
Efsanesi(단군신화) ${ }^{13 \prime}$ nde ay1 ve kaplan yer alırken, Goguryo(고구려, m.ö.37 m.s.668)'nun kuruluş efsanesinde ise kuş, at, kaplumbağa, ulusun atası Cumong(주몽) ile bağlantılı olarak ortaya çıkmaktadır. ${ }^{14}$ Yine Şilla(신라, m. ö. 57 m.s.935)'nın kuruluş efsanesinde yer alan at ve tavuk önemli karakterlerdir. ${ }^{15}$ Bunun gibi kuruluş efsanelerindeki hayvanlar, başkahramanın ortaya çıkışını bildiren haberci rolünü üstlenmişlerdir. Bununla birlikte hayvanların üstün varlıklar olduğunu anlatan bir karakter olarak yer almaları, başkahramanın kutsallığını kanıtlayan bir sembol olarak da görülmektedir. Bu yüzden hayvanların kutsallığı bir inanç olarak yer edinmiştir. Ayrıca hayvanlar sadece sıradan bir hayvandan ibaret olmayıp inanç ve kültür sembolü olarak da anlam taşır hale gelmiştir. ${ }^{16}$

Bir de hayvan motifleri kutsallık barındırmakla birlikte yaşanılan dönem toplumunu yansıtan bir sembol sayılır. Bu yüzden hayvan motiflerini analiz etmek sadece barındırdıkları sembolik anlamları algılamakla kalmayıp yansıtılan toplum durumunu da incelemeyi sağlar. ${ }^{17}$ Özellikle Şilla'nın kuruluş efsanesindeki at ve tavuk sembolleri kral ve kraliçeyle ilgili olarak görünmektedir. Bu hayvan sembolleri, kralın kutsallığını gösteren haberci bir varlık olmasıyla, diğer hayvan sembollerine göre kralın ortaya çıkışıyla ilgili olduğundan dolayı özellikle saygı duyulmuş ve kutsal görülmüştür. ${ }^{18}$ Başka bir örnek vermek gerekirse, Gyongnam(경남) bölgesi Ulsan Bangude(울산 반구대)'deki petrogliflerde balina, kaplumbağa, fok balığı gibi deniz canlıları ile kaplan, geyik, inek, domuz ve leopar gibi hayvanların insanlarla birlikte çizildiği görülmektedir. Böyle hayvan resimleri yalnızca sanat eseri olmadı̆̆ı, bereket ve doğurganlığı dileyen dini ve büyüsel bir anlam taşıdığı tahmin edilmektedir. ${ }^{19}$ Böyle büyüsel ve simgesel nitelik taşıyan hayvan resimleri, Goguryo'ya ait Muyong(무용) mezarlığındaki av resimlerinde de

\footnotetext{
${ }^{13}$ Dangun Efsanesi(단군신화), Kore'nin ilk devleti olan Kocoseon(고조선, m. ö. 2333 108)'un kurucusu olan Dangunwanggeom(단군왕검)'un doğum efsanesidir; 한국민족문화대백과, "단군신화", https://terms.naver.com/entry.nhn?docId=534286\&cid=46620\&categoryId=46620 (Giriş tarihi, 07, Mayıs 2020)

14 일연, 삼국유사, 기이 제1권, "고조선", 20,"고구려", 47-49.

15 일연, 삼국유사, 기이 제1권, "신라 시조 혁거세왕", 8-59.

16 이현주, 신라의 건국신화와 동물 상징, 3.

17 이현주, 신라의 건국신화와 동물 상징, 3.

18 이현주, 신라의 건국신화와 동물 상징, 30.

19 황나현, 조선시대 동물화의 상징성과 조형성에 관한 연구, 석사논문, 홍익대학교, 2012, 9-10; 이현주, 신라의 건국신화와 동물 상징, 4-6.
} 
görülmektedir. Bu tarz mezar duvarı resimleri sadece görsel amaçla çizilmiş sanatsal resimler değil, aynı zamanda bereketi ya da umudunu gerçekleştirebilecek bir büyüsel anlamlar da taşımaktadır.

Kore folklorunda insanlarla birlikte yaşayan evcil hayvanlar, genelde varlık, statü ve huzur getiren hayvanlar olarak görülür. Vahşi hayvanlar ise genellikle kötü ruhları kovma anlamı taşımakla beraber uzun zamanlar boyunca insanların zihninde özel bir sembolik anlama sahiptir. ${ }^{20}$ Örneğin kaplan, korkulan ve kutsal bir hayvan olarak düşünülür. Bu yüzden kral mezarları ya da kulelerde kaplan heykeli sıklıkla görülmektedir. ${ }^{21}$ Ayrıca Kore kültüründe fare, yılan, domuz gibi hayvanlar zenginliği simgelemektedirler. Bu hayvanlar sadece zenginliği temsil etmekle kalmayıp inançsal varlıklar olarak da yer edinmişlerdir. ${ }^{22} \mathrm{Bu}$ da, Kore halkının inançsal özelliklerinin gözlemlenebileceği bir veri olmaktadır.

Deyim ve atasözlerinde hayvanlar, kendi özel kavram anlamları dışında görünüş ya da alışkanlık, kişilik vb. herhangi bir yönden gözlemlenip bu gözlemlenen özelliklerine göre uygun bir sembol anlamı ile nitelendirilerek insanların karmaşık halini ve karakter özelliklerini göstermektedir. ${ }^{23}$ Yani hayvanların çeşitli niteliklerini, benzetme unsuru olarak kullanarak insanların zihniyetini ve değer yargılarını barındıran bir ifade yöntemidir. Hayvan motifleri, insanların duygu durumları ya da içine düştükleri durumlar gibi soyut kavramları ayrıntılı ve somut bir şekilde gösteren bir ekipman olarak gerçekçi ve canlı olup doğrudan iletim etkisi oluşturmaktadır. Böylelikle özel hayvanlara verilen mecaz anlamları çağrıştırılmaktadır. ${ }^{24}$ Örneği, Kore'de ejderha genellikle 'başarı' anlamına gelir ve 'rüyada ejderha ya da domuz görmek' ise, şans olarak algılanır. Özellikle atasözlerindeki hayvanların olumsuz sembol ya da renkleri, hayvanların kendilerinin gerçek şekilleri, özellikleri ve rolleri hakkındaki genel anlayışı olduğu gibi yansıtmaktadır. ${ }^{25}$ Genel olarak baktığımızda dış görünüşü kusursuz ve değerli görülen hayvanlar olumlu semboller olarak gösterilip, dış görünüşü çirkin ve kötü görülen hayvanlar olumsuz sembol olarak gösterilmektedir. Mesela kaplan veya at daha duygusal bir his

\footnotetext{
20 황나현, 조선시대 동물화의 상징성, 8.

21 황나현, 조선시대 동물화의 상징성, $18,22-23$.

22 김종대, "므을 통해본 뭄", 175.

23 김수령, 중·한 관용어에 묘사된 $12 \square$ 동물의 상징의미 비교 연구, 석사논문, 부산외국어대학교, 2011, 27.

24 김수령, 중·한 관용어에 묘사된 $12 \square$ 동물, 27.

25 김종대, "므을 통해본 무", 174-175.
} 
uyandırır, yılan ya da fare gibi hayvanlar kötü ve çirkin şeyleri ifade eder. Genelde hayvanların gerçek özellikleriyle olumsuz imajları neredeyse aynidir.

Fabllar, insanlar dışında canlılar ya da cansız varlıkları karakterize edip onlara yer veren ve aralarındaki diyalog ya da davranışlara dayanarak toplum terbiyesini öğütleyen ya da mizah yapmayı amaçlayan edebiyat yöntemidir. ${ }^{26}$ Hayvan fabllarında hayvanlar genelde kişileştirilerek insan gibi davranan tipik başrol olarak ortaya çıkmakla birlikte özellikleri de tipikleştirilmiştir. Mesela tilki kurnaz, kurt açgözlü, aslan cesur ve onurlu bir şekilde çizilmiştir. Bu yüzden fabllar, topluma samimi ve aydınlatıcı bir şekilde yaklaşmasıyla sevilerek okunmaktadır. Ahlaki öğütler barındıran bu fabllar ironik, gerçekçi ya da bazen mizah da içermektedir. ${ }^{27}$

\section{Kore'de 12 Hayvanın Sembolleri ve Anlamları}

'십이지(Şibici)', yani 12 hayvanlı takvim; yıl, ay ve saatlerin hayvanlarla ifade edildiği bir takvimdir ve 12 hayvandan oluşması da bir yılın 12 ay olmasındandır. 12 yıl bir devreyi oluşturur ve bir devrenin 5 kez dolaşmasıyla 60 yılda bir dolaşımı pekiştirir. ${ }^{28} 12$ hayvanlı takvim; fare, sığır, kaplan, tavşan, ejderha, yılan, at, koyun, maymun, tavuk, köpek ve domuzdan oluşur. ${ }^{29} 12$ hayvanın ayrı ay, saat ve yönlere dizilmesinin nedeni ise, hayvanların ayak parmak sayısı ve her hayvanın etkin olduğu saatlere göre

26 김정진, "카프카의 문학 작품에 나타난 동물군상의 상징적 의의", 카프카연구, $1(1984,6)$, 카프카학회, 254.

27 이유진, 새의 이야기를 담은 장신구, 석사논문, 국민대학교, 2011, 5.

${ }^{28}$ Şeref Boyraz, "12 Hayvanlı Türk Takvimi ve Kehanet", Uluslararası Sosyal Araştırmalar Dergisi, Cilt 3, Sayı 14(Güz 2010), s. 152-153; Fikret Türkmen, "Türk kültüründe tarihi girişim içinde hayvan ve bitkilerin "Ölçü Birimi" olarak kullanılması hakkında", Milli Folklor, Cilt 24, Sayı 95(2012), 98.

${ }^{29} 12$ hayvanlı takvimine Doğu ve Batı'ya yayılıp geniş kapsamlı bir şekilde Japonya'dan Doğu Avrupa'ya kadar uzanan, eski Çin ve Türk kültürlerinin etki sahasına giren geniş bir coğrafyada rastlamaktadır. Çin kültürü Doğu ve Güney Asya'daki farklı toplumları etkileyerek 12 hayvanlı takvim sistemini yayarken, bu takvim eski Türk kültürü vasıtasıyla Altay-Sibirya, Orta Asya, Kafkasya, Doğu Avrupa topraklarında yaşamakta olan Türk halklarının kültürel yapılarında da önemli bir unsur olmuştur. Yine 12 hayvanın yapısı her ülkenin bölgesel, kültürel özelliklerine göre küçük farklılıklar gösterir. Vietnam'ın 12 hayvanlı takviminde tavşan yerine kedi, Hindistan'ın takviminde ise kaplan yerine aslan, tavuk yerine de Hindistan'ın tavus kuşu konulmuştur. Eski Türk 12 hayvanlı takviminde ejderha yerine bazen balık bazen de timsah, kaplan yerine pars yer almaktadır; 이종관, "민화에 나타난 십이지동물의 민속의식에 관한 연구", Journal of the Korean Academia- Industrial Cooperation Society, 17(2016, 6), s. 348; Ufuk Tavkul, "Kültürel Etkileşim Açısında On İki Hayvanlı”, s. 26; Yavuz Unat, “İslâm' da ve Türklerde Zaman ve Takvim", 18. 
dizildiği söylenir. 12 hayvanlı takvim, astronomi bilgileri ya da soyut kavramları sembolik olarak ifade etmek için doğu felsefesi Yin-Yang beş element temelinden oluşan bir tür evrensel sembol olarak düşünülmektedir. ${ }^{30}$

\subsection{Fare Yılı ve Fare Figürü}

Fare yılı (쥐띠), 12 hayvanlı takvimde ilk sırada yer alır. Fare yılı olan yıllar 1972, 1984, 1996, 2008 ve 2020 gibidir. Bu çalışmada aşağı yukarı elli sene içerinde hayvan yılları bu şekilde gösterilmektedir. Bunun özel bir sebepten değil de, halen Kore'de bu takvimin kullanılmakta olduğunu belirtmek amacıdır. Zira 12 hayvanlı takvim halen Korelilerin günlük yaşamında etkisini sürdürmektedir.

Kore kültüründe fare iki farklı tarafı olan bir hayvandır. Eski zamanlarda kutsal bir hayvan olarak kabul edildiği gibi alçak bir hayvan olarak dışlanmışlığı da vardır. ${ }^{31}$ Fare 'akıllı' 'uyanık' gibi genel fikirlerin yanı sıra fazla üreyen bir hayvan olduğundan dolayı doğurganlık ve bolluğun simgesi olarak da görülmüştür. Ayrıca herhangi bir yere kıvrak bir şekilde girip çıkabildiği canlı hareket gücü doğal olarak çalışkanlık anlamını da kapsamaktadır. ${ }^{32}$

12 hayvanlı takvimde en küçük ve değersiz olan farenin ilk sıraya konulmasıyla ilgili olarak eğlenceli bir hikâye aktarıla gelmiştir. Bu efsane, farenin akıllılığını ve uyanıklığını simgeleyen bir arka plan da olmuştur;

"Eskiden tanrı, hayvanlara toplanmalarını söyleyip, hızlı gelme sıralarına göre 12 hayvanın günün saatleri ve yönlerini anlamlandıracağını söyler. Toplanma yerine en önce ulaşan sığırın sırtında gelen fare bir adım zıplayarak birinci olur. Böylelikle sığır, kaplan vb. 12 hayvan gelir ve 12 hayvanlı takvim belirlenir." 33

Kore'nin yaratılış efsanelerinde fare, su ile ateşin kaynağını bilen, onu insanlara getiren ve geleceğe dair bir gerçeği sezebilen kutsal bir hayvan

\footnotetext{
30 한예민, 십이지 동물의 설화화 양상과 의미- 한국구비문학대계를 중심으로-, 석사논문, 숭실대학교, 2012, 12.

31 리예, 한·중 12디 동물의 상징의미 대조를 통한 한국어 교육용 관용어 연구, 석사논문, 중앙대학교, 2018, 17; 한예민, 십이지 동물의 설화화 양상과 의미, 13.

32 김수령, 중'한 관용어에 묘사된 $12 \square$ 동물, 34.

33 송영숙, "한일 십이지 동물설화의 비교연구- 쥐 모티프의 상징을 중심으로-", 한국일본어문학회 학술발표대회논문집, 한국일본어문학회, 2008, 387.
} 
olarak karşımıza çıkar. ${ }^{34}$ Yine Kore masallarında fare önceden bilme yeteneklerini kullanarak kendisine iyilik yapan insanlara karşı iyiliğinin karşılığını öder. "혼 쥐 이야기 (Cin fare hikayesi)" 35 ya da "쥐 이야기 (Fare hikayesi )" 36 gibi masallar da bunun birer örneğidir. Bir de kötü bir olay ya da doğal afetleri engellemeye yardım eder. ${ }^{37}$

Bunun tersine fare yiyecek çalıp eşyaları kemiren ve bolluğu götürüp hastalık taşıyarak musibet getiren pis bir hayvan olarak da algılanır. Ayrıca fare sadece karanlık yerlerde gezmesi ve küçük vücudu yüzünden hainliği simgeler. ${ }^{38}$ Bundan dolayı zavallı ve değersiz varlıklar fare ile kıyaslanır. Farenin çalışkanlığı olumsuz bir şekilde hırsın simgesi olarak da ifade edilir. Bunun yanında fare hain, sömürücü ve hırsız kavramı ile eşleşmiştir. ${ }^{39}$

Dolayısıyla Kore deyim ve atasözlerinde fare alçak, küçük ve değersiz şeyleri simgeleyerek zayıf ve yeteneksiz insan ya da haini ima eder. ${ }^{40}$ "쥐뿔 (Fare boynuzu)" ifadesi, farenin boynuzu olmadı̆̆ından yok veya hiç anlamını taşıyarak çok az ve küçük anlamında kullanılır ve "쥐구멍(Fare deliği)" ise, çok küçük ve zavallı bir yeri ima eder. Ayrıca birinin değersiz ve zavallı hali "물에 빠진 생쥐 (Suya düşmüş fındık faresi)" olarak ifade edilir. ${ }^{41}$ Deyimlerde farenin özellikle kedi ile birlikte kullanılması güçlü ve güçsüz arasındaki ilişkiyi açıkça ifade eder. "고양이 앞에 쥐 (Kedinin önünde fare)" ifadesi güçlü kimsenin önünde kılını bile kıpırdatamayan güçsüz yahut zayıf kimsenin durumunu gösterir. "고양이 쥐 생각하다 (Kedinin fareyi düşünmesi)" ise güçsüzlere acıması değil tıpkı kedinin fareyi yem olarak görmesi gibi, mahvolmasını dilediği anlamını içerir. ${ }^{42}$ Aynı anlam açısından

\footnotetext{
34 리예, 한·중 12 띠 동물의 상징의미, s. 17; 축산경제신문, "세시기-올해는 경자(ㅁ)년 흰 쥐띠 해", http://www.chukkyung.co.kr/news/articleView.html?idxno=56246, (Erişim tarihi, 07 Mayıs 2020)

35 축산경제신문, "세시기- 올해는 경자(ㅁ)년 흰 쥐띠 해", http://www.chukkyung.co.kr/news/articleView.html?idxno=56246, (Erişim tarihi, 07 Mayıs 2020) 36 한국향토문화전자대전, "쥐 이야기",

https://terms.naver.com/entry.nhn?docId=2650310\&cid=51888\&categoryId=53642, (Erişim tarihi, 08 Mayıs 2020)

37 한예민, 십이지 동물의 설화화 양상과 의미, 25-26.

38 이종관, "민화에 나타난 십이지동물", 356.

39 김수령, 중·한 관용어에 묘사된 $12 \square$ 동물, 34; 리예, 한·중 12띠 동물의 상징의미, 18.

40 우연미, 성어 속 띠 동물의 상징의미 연구, 석사논문, 강원대학교, 2008, 9.

41 리예, 한·중 12 띠 동물의 상징읨/, s. 19; 김수령, 중· 한 관용어에 묘사된 $12 \square$ 동물, 35-36.

42 김수령, 중·한 관용어에 묘사된 $12 \square$ 동물, 40.
} 
"쥐 죽은 듯이 (Fare ölmüşçesine)" sözü korku ya da tehlikeyi hissedip kılını bile kıpırdatamayıp doğru düzgün nefes bile alınamayan durumu ifade eder ayrıca sessizliği mecazi olarak ifade eder. Yine "독 안에 든 쥐 (Tuzağa düşmüş fare)" ifadesi tek başına bırakılmış veya ne kadar çabalasa da içinden çıkılamayan durumu ifade etmede kullanılır. ${ }^{43}$

\subsection{Siğır Yılı ve Siğır Figürü}

Sığır yılı(소띠), 12 hayvanlı takvimde ikinci sırada yer alarak 1973, 1985, 1997, 2009 ve 2021 gibi senelerden oluşur. Tarımı temel ekonomik gelir kaynağı olarak benimseyen Kore ulusu için çok eskiden beri sığır, diğer hayvanlara göre daha yaygın olmasının yanı sıra çiftliklerin en önemli sermayesidir. Kore halkı Sığır için 'senğgu(yaşayan ağız)' sözcüğünü de kullanmıştır. 'Senğgu(생구)' kelimesi evde yaşayan hizmetçi ya da uşak anlamına gelmektedir ve bu da Korelilerin sığırı bir aile ferdinden ayırt etmediklerini göstermektedir.

Sığır, tarlada çalışmasının yanı sıra taşıma aracı görevi de üstlenmiştir. Ayrıca para edebilecek mali değeri de vardır. Tarım alanında en büyük sermaye olan sığır, zenginlik göstergesi olduğundan bolluk getirip kötü şeylere mani olan bir varlık olarak düşünülmüştür. Bu yüzden eski çağlardan bu yana hasat bayramı törenlerinde kurban edilen hayvan olarak da kullanıla gelmiştir. ${ }^{44}$

Koreliler sığırları samimi birer arkadaş olarak görür ve onların sadakat, bağlılık, gayretli çalışma ve dost canlısı gibi üstün meziyetleri olduğunu düşünürler. Bu nedenle sığırlar, ağır ve zor eşyaları iyi taşıyan ve çiftçilere yardımcı olan önemli evcil hayvanlar oldukları için üstün kişileri temsil eder. Folklorda bir tür zenginlik göstergesi olarak addedilen sığır, güçlü, çalışkan, dürüst ve ağırbaşlı hayvan olarak algılanır. Sığırların yüklenmiş olduğu bu anlam, Kore masallarında da görülmektedir. Mesela "소가 된 게으름뱅이(Sı̆̆ıra dönüşen temel çocuk)“masalı, tembel çocuklara sığırın sadakatli oluşunu ve çalışkanlığını anlatan öğüt verme amaçlı bir hikayedir. ${ }^{45}$ Sığırlar, saf, temiz ve dürüst, sabırlı doğası nedeniyle sevilirler. Ayrıca eski âlimlerin dünyadan uzaklaşıp inzivaya çekildiklerine dair meyillerini de sembolize etmektedirler. Öte yandan dürüst ve inatçı olduklarından, zaman

\footnotetext{
43 리예, 한·중 12 띠 동물의 상징의미, 18.

44 한예민, 십이지 동물의 설화화 양상과 의미, 12-13.

45 한예민, 십이지 동물의 설화화 양상과 의미, 27-28.
} 
zaman saf ve aptal anlamını da barındırır. ${ }^{46}$ Ayrıca sığır işini yaparken yavaş hareketleri, ilgisiz tepkileri nedeniyle insanları olumsuz düşünceye sevk etmiştir.

Onlara ait bu tür özellikler genellikle insanların dili ve davranışlarıyla bağdaştırılır. Birinin inatçı ve başına buyruk karakterini ifade ederken, sığırın

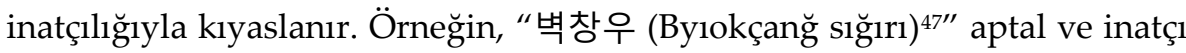
biri için söylenen bir sözdür. Dahası "소 죽은 귀신 같다 (Sığırı ölmüş hayalet gibi)" ve "황소고집(Öküz inadı)" gibi deyimler sert ve inatçı insanlar için kullanılan ifadelerdir. ${ }^{48}$ Ayrıca sığır büyük cüsseli olmasının yanı sıra derisi de kalın ve serttir. Dolayısıyla içinin nasıl olduğu bilinmediğinden utanmazlık, sertlik ve sinsiliğin birer sembolü olarak da kullanılır. "낮짝이 소가죽보다 두껍다 (Yüzü sığır derisinden daha kalın)" veya "쇠가죽 같다(Sığır derisi gibi)" türündeki ifadeler, utanmazlık ve edepsizliği ima eden deyimlerdir. "소 귀에 경읽기 (Sığır kulağına ilahi okuma)" atasözü ise insanın saf ve aptallığını ifade ederek vurdumduymazlık anlamında kullanılır. ${ }^{49}$

Doğu-Batı eski ve günümüz ressamları, sığır resimleri vasıtasıyla insanlık tarihi ile doğanın ilişkisini, kendi kimliklerini ortaya sererek inanç ve iradelerini mizahi açıdan ortaya koymuştur. Kore halk resimlerinde sığırlar resmedilirken genellikle gerçekçi değerlerinden ziyade bolluk, yalnızlık, hayırseverlik, cömertlik, özgürlük gibi pozitif yönleri üzerine daha büyük bir ağırlık yüklenmiştir. Sı̆̆ırların doğası ve nitelikleriyle ilgili sembolizme daha da önem vermiştir. ${ }^{50}$ Ayrıca Kore folklorunda sığır heykeli yapma veya birine sığır resmi gönderme gibi adetler iyi bir hasat dilemeyi, tarım zamanını bildirme ve gayretle çalışma anlamlarında kullanılmıştır. Sığır ailenin ve çiftçiliğin gelişmesi için iyi bir işaret anlamına da gelmektedir. ${ }^{51}$

\footnotetext{
46 리예, 한·중 12 띠 동물의 상징의미, 21; 우연미, 성어 속 띠 동물의 상징의미 연구, 13-16; 이종관, "민화에 나타난 십이지동물", 356-357.

47 벽창우 (Byıkçanğ sığırı) yazılımında sığır anlamına gelen '우()' harfi Çincenin Korece yazılışıdır.

48 김수령, 중·한 관용어에 묘사된 12 동물, s. 42-43; 리예, 한·중 12 띠 동물의 상징의미, 22-23; 정연학, "소에 나타난 민속학적 의미와 상징- 한국과 중국을 중심으로-", 민속학연구, 6(1999, 11), 국립민속박물관, 482.

49 김수령, 중·한 관용어에 묘사된 $12 \square$ 동물, $42-44,47$.

50 이종관, "민화에 나타난 십이지동물", 349.

51 정연학, "소에 나타난 민속학적 의미", 480.
} 


\section{3. Kaplan Yılı ve Kaplan Figürü}

Kaplan yılı (호랑이띠), 12 hayvanlı takvimde üçüncü sırada yer alıp 1974, 1986, 1998, 2010 ve 2022 gibi senelerden oluşur. Kore'de kaplan, dağların koruyucusu, yağmur duası için adak ve koruyucu tanrının simgesidir. ${ }^{52}$ Yine mutlak otorite ve gücü temsil ettiğinden yiğitlik, şeref, kuvvet, askeri unvanlar, ordu ve zafer gibi kültürel anlamları da barındırır. Kaplanın yiğitliği, genelde ordunun ismi ve ordunun bayrağı olarak kullanılır. ${ }^{53}$ Yine hastalıkları ya da kötü hayaletleri kovan ruh kovucusunu simgeleyen kaplan resmi, tılsım olarak da kullanılmıştır. ${ }^{54}$ Özellikle beyaz kaplan, Taoizmde temsili kutsal hayvan olup kralın mezarının koruyucusu olarak değerlendirilirdi. ${ }^{55} \mathrm{Bu}$ yüzden Kore halkının his ve düşüncelerinin kaplan aracılığıyla yansıtıldığı görülür. Dolayısıyla kaplan, Kore ulusu kuruluş efsanesi olan Dangun Efsanesi'nde yer alarak halen Kore halkının hislerini temsil eden bir hayvan olarak anılmaktadır. Kaplan, yiğitliği ve koruyucu tanrı olarak simgelenmesiyle 1988 Seul Olimpiyatları ve 2018 Pyongçang (평창) Kış Olimpiyatları'nda maskot olarak seçilecek kadar Kore'yi temsil eder olmuştur.

Diğer yandan kaplan, zulüm, vahşilik, büyük zorluk ve tehlikeyi de simgeler. Tehlike ya da felaketi getiren acımasız ve yırtıcı bir hayvan olması sebebiyle başkalarına kötü davranan cani ya da kötü insan, kaplan olarak sembolize edilir. ${ }^{56}$ Ayrıca kaplan, iyiliğe iyilikle karşılık veren ahlaklı bir hayvan olarak anılmasının yanı sıra eski masallarda zarara uğrayan gülünç, akılsız bir hayvan olarak halka öğüt veren samimi bir karakter olarak da ortaya çıar. Bununla birlikte yolsuzluk yapan memur, kurnazlık, adilik gibi olumsuz ögeleri de simgeler ${ }^{57}$ Ancak rüyada görülen kaplan; şeref, güç, zafer gibi şeyleri simgeler ve kaplan ile doğrudan temasın olduğu rüyalar ise en hayırlı rüyalardan sayılır. ${ }^{58}$

\footnotetext{
52 한예민, 십이지 동물의 설화화 양상과 의미, 14.

53 우연미, 성어 속 띠 동물의 상징의미 연구, 23-24; 김태영, 동물의 원형적 상징과 조형의식, 12.

54 이종관, “민화에 나타난 십이지동물", s. 350; 허은아, 신라의 동물형토우에 관한 연구, 18 ; 한예민, 십이지 동물의 설화화 양상과 의미, 14.

55 김태영, 동물의 원형적 상징과 조형의식, 12 ; 강민경, “遊仙文學에 나타난 道敉의 동물에 대한 형상과 인식”, 동방한문학, 62(2015), 동방한문학회, 36; 김은선, “조선 왕릉 石獸연구“, 미술사학연구, 283.284 $(2014,12), 66$.

56 리예, 한.중 12 띠 동물의 상징의미 s. 25; 김수령, 중' 한 관용어에 묘사된 12 支동물, 50.

57 한예민, 십이지 동물의 설화화 양상과 의미, 34, 37-38.

58 김수령, 중· 한 관용어에 묘사된/12공동물, 50.
} 
Kaplan, deyim ve atasözlerinde ruhani bir hayvan olarak kahraman anlamını taşımasının yanı sıra insanları korkutan tehlikeli bir hayvan olarak da ifade edilir. Yine de Kore kültüründe en yaygın kaplan imajı, otorite ve gücün simgesidir. 59 "범의 어금니 (Kaplanın azıdişi)" 60 ifadesi olmazsa olmaz, önemli şey anlamına gelir. Bunun yanı sıra "인왕산 호랑이 (İnvanğ Dağ1 kaplanı)" ifadesi korkutucu bir kimseyi, “발톱 없는 호랑이 (Ayak tırnağ olmayan kaplan)” ve “이빨 빠진 호랑이 (Dişi düşmüş kaplan)” ifadeleri ise gücünü ya da otoritesini kaybetmiş kimseleri ima eder. ${ }^{61}$ Güçlü ve korkusuz kaplan, doğal olarak korkunç ve tehlikeli bir varlık ile bağdaştırılır ve kaplanın vücut bölümleri ya da yaşadığı mağara gibi onunla bağlantılı öğelerin tümü tehlikeyi temsil eder. “범의 아가리 (Kaplanın ağzı)” ifadesi çok tehlikeli bir durumu ima eder, “범의 아가리를 벗어나다 (Kaplanın ağzından kurtulmak)" ise çok tehlikeli bir durumdan çıkmak anlamına gelir. "호랑이 새끼를 기르다 (Kaplan yavrusu büyütmek)" deyimi ise, düşman haline gelebilecek birini yetiştirmek anlamında olup, potansiyel olarak felaket olabileceğini simgeler. ${ }^{62}$

Genellikle kaplan Kore'de en korkunç yırtıcı hayvan olarak tanına geldiğinden dolayı tüm hayvanların kralı olmakla birlikte yeryüzünde korktuğu bir şey olmayan mutlak bir varlık olup tüm hayvanların ve insanların düşmanı olarak görülür. "호랑이와 곶감 (Kaplan ve Kuru hurma)” adlı masalda kötü karakter olarak karikatürize edilen kaplan sembolü şu şekildedir;

“Kaplan ve inek hırsızı ayrı ayrı inek çalmak için bir köye gizlice girer. Köydeki evlerden birinde bir çocuğun ağlama sesi duyulur ve annesi kaplan geldi diye çocuğu korkutmaya çalışsa da çocuk ağlamayı kesmez. Fakat kuru hurma sözünü duyunca çocuk ağlamayı bırakır. Bu yüzden olanları gizlice izlemekte olan kaplan kuru hurmanın dünyadaki en korkunç şey olduğunu düşünür. Kaplanı inek sanan inek hırsızı ise kaplanın sırtına binince, kaplan kuru hurma geldiğini sanıp kaçmaya başlar. Bir süre sonra tekrardan köye gelen kaplan pazarda bir tüccarın kuru hurma sattığını duyup korkar ve kaçar." 63

\footnotetext{
59 우연미, 성어 속 띠 동물의 상징의미 연구, 24.

60 범의 어금니(Kaplanın azıdişi) yazılımında ‘범`kelimesi, kaplan anlamına gelen öz Korecesidir.

61 김수령, 중· 한 관용어에 묘사된/12하동물, 52.

62 리예, 한. 중 12 띠 동물의 상징의미, 25-26; 김수령, 중· 한 관용어에 묘사된 12 支동물, 55.

63 한예민, 십이지 동물의 설화화 양상과 의미, 37.
} 
Bu hikâyede küçük bir hayvan ya da bir insanı yakalayıp yemeye çalışan kaplan, aksine zarara uğrayarak gülünç bir duruma düşüp okuyuculara eğlenceli bir an yaratır. Burada kaplan sadece hayvansal bir sembol değil, kral ya da siyasetçiyi simgeler. Bu açıdan bakılırsa halkın, beceriksiz ve tembel bir siyasetçiyi kaplan olarak sembolize etmesi masallara yansıtılmıştır. ${ }^{64}$

\subsection{Tavşan Yılı ve Tavşan Figürü}

Tavşan Yıl1(토끼띠), 12 hayvanlı takvimde dördüncü sırada yer alarak 1975, 1987, 1999, 2011 ve 2023 gibi senelerdir. Kore kültüründe tavşan; küçük, sevimli, iyi kalpli ve hızlı hareket eden zeki bir hayvan olarak bilinir. Kore halk hikâyelerinde tavşan, küçük ve güçsüzdür. Fakat hızlı ve kendi sahip olduğu zekâsıyla fiziki olarak kendisinden büyük ve güçlü hayvanlara karşı gelip yenilmez veya onlar tarafından sömürülemez. ${ }^{65}$ Ayrıca tavşan karakteri, aceleci ve şımarık davranışlar göstermesi ve hızlı hareketlerinin yanı sıra ürkekliği de temsil eder. ${ }^{66}$

Genellikle Kore halkı ay ve tavşanı, bereket ve bolluk timsali olarak kabul ederler. ${ }^{67}$ Eskiden insanlar gece gökyüzüne baktığında tarçın ağacı altında ölümsüzlük otunu havanda döven tavşanı düşünerek, tavşan gibi binlerce yıl huzur ve bolluk içerisinde herhangi bir endişe olmaksızın ideal bir dünya hayalini kurmuşlardır. Tavşan uzun ömür sembolü ve ayın ruhudur. ${ }^{68}$ Ancak tavşanın eskiden sahip olduğu kutsallık neredeyse kaybolup, günümüzde yeryüzündeki diğer hayvanlardan daha üstün bir zekâya sahip olan bilgelik sembolü olarak görülmektedir. ${ }^{69}$

Tavşanla ilgili masalların çoğunda onun zekâsına değinilmiştiir7;

“별주부전(Byolcubucon)" adlı masalda deniz kralı hastalanır ve hastalığından kurtulmanın çaresi tavşanın karaciğeridir. Kral tavşan karaciğeri bulması için kaplumbağayı görevlendirir. Kaplumbağa tavşanı bulup kandırarak deniz sarayına götürür. Durumu anlayan tavşan, kendi karaciğeri çok değerli olduğundan her zaman yanında taşımadığını arada

\footnotetext{
64 한예민, 십이지 동물의 설화화 양상과 의미, 38.

65 리예, 한.중 12 띠 동물의 상징의미, 28-29.

66 김수령, 중· 한 관용어에 묘사된 12 支동물, 57.

67 한예민, 십이지 동물의 설화화 양상과 의미, 14-15; 이종관, “민화에 나타난 십이지동물”, 357.

68 금영진, “흰색 십이지 동물 상징성의 한일비교", 동방학, $66(2017,1)$, 단국대학교 동양학연구원, 52.

69 한예민, 십이지 동물의 설화화 양상과 의미, 40.

${ }^{70}$ 송영숙, “한일 토끼 설화의 비교 연구- 트릭스터의 유형을 중심으로-“, 일본문화학보, $69(2016,5)$,

일본문화학회, 276.
} 
yıkayıp ağaca asarak kuruttuğunu söyler. Buna kanan kaplumbağa tekrar tavşanı karaciğerini alması için karaya çıkarır. Tavşan kaplumbağanın sırtından inince alay ederek kaçar. Bu masalda tavşanın zekası öne çıkmaktadır. Bir de tavşanın karaciğeri masalda özel bir ilaç olarak bahsedildiğinden tavşan, aynı zamanda uzun ömür ve ölümsüzlük temalarını da simgeler. ${ }^{71}$

"지혜로 호랑이를 잡은 토끼 (Hileyle Kaplanı Yakalayan Tavşan)" masalında, soğuk bir kış gününde kaplana yakalanan tavşan, eğer kuyruğunu derenin suyuna sokarsa çokça balık tutabileceğini söyleyerek onu kandırır. Buna inanan kaplan, suya kuyruğunu sokarak soğuktan donar ve ölür. ${ }^{72} \mathrm{Bu}$ hikâyede kaplan yönetici sınıfı, tavşan ise halkı temsil eder. Yani, tavşanın zekice bir hileyle kaplanı kandırabildiğini anlatan bu hikâyeyle halkın teselli alması istenmiştir. Eski masallarda kaplan sadece bir hayvan değil, otorite ya da makam aracılığıyla kendi çıkarını sağlayıp başkalarına zorbalık yapan soyluları ve yöneticileri, tavşan ise kaplanın karşısında ezilen ve mağdur olan halkı temsil etmektedir. Tavşanın kaplanı kandırıp acı çektirmesi, soyluların ya da idarecilerin haksızlığını konu almaktadır. Güçsüz insanlar, kendisinden daha güçlü insanları yenmek için zekâlarını kullanmalıdır. Bu masal da güçsüz halde daima ezilen halkın nasıl hayatta kalabileceğine ve zekâsını nasıl kullanması gerektiğine dair bir öğüt olabilir. ${ }^{73}$

Tavşan, zeki ve kurnaz olmasına rağmen ürkek bir hayvandır. Bu yüzden Kore'nin atasözlerinde ürkek bir insan ya da çok şaşırtıcı bir durumdan bahsederken "놀란 토끼 눈을 하다 (Gözünü tavşan gibi açmak)" diye ifade edilir. ${ }^{74}$ Ayrıca avcılıkta en çok avlanan hayvan tavşandır. Dolayısıyla tavşan, avlanma ve avcılık hedefi anlamında kullanılır. Örneğin, “두 마리 토끼를 잡다 (İki tavşan yakalamak)"75atasözü aynı anda iki işi yapmak anlamına gelmektedir. ${ }^{76}$

\subsection{Ejderha Yılı ve Ejderha Figürü}

Ejderha yıl1(용띠), 12 hayvanlı takvimde beşinci sırada yer alıp 1976, 1988, 2000, 2012 ve 2024 gibi senelerden oluşur. Ejderha, Doğu-Batı fark etmeden

\footnotetext{
71 김수령, 중· 한 관용어에 묘사된/12공동물, 56.

72 한예민, 십이지 동물의 설화화 양상과 의미, 40.

73 한예민, 십이지 동물의 설화화 양상과 의미, 41

74 김수령, 중'한 관용어에 묘사된 $12 \square$ 동물, 59.

75 Türkçe atasözü olarak "Bir taşla iki kuş vurmak" demektir.

76 김수령, 중·한 관용어에 묘사된 12 동물, 59.
} 
tarih olsun kültür olsun her alanda birçok yönden etki yaratan hayali bir hayvandır. Genellikle ejderha, Batı'da kötülük tanrısı olarak ortaya çıkarken Doğu'da mutlak krallığ sembolize eden koruyucu ve evren düzenini yöneten tanrı rollerini üstlenmektedir. ${ }^{77}$ Ejderha, Çin'i merkez alan Doğu'da gizemli bir hayvan olup, zürafa, kaplumbağa ve anka kuşu ile birlikte uğurlu bir hayvan olarak bilinir. Bu yüzden ejderha, kralı ya da bir kahramanı simgeler ve “입신출세 (Başarılı olup dünyaya adını duyurmak)" anlamına gelen deyimde sıklıkla kullanılır. ${ }^{78}$

Ejderha, 12 hayvanlı takvim arasında tek hayali hayvandır. Diğer 11 hayvan olumluluk ve olumsuzluğun iki yüzünü aynı anda barındırırken, ejderha sadece olumluluğu sembolize eder. Ejderha, umudu simgeleyen bir hayvan olmasının yanı sıra yeryüzündeki mutlak otoriteyi temsil eden bir hayvan olarak tapınıla gelmiştir. ${ }^{79}$ Yine ejderha su tanrısı olup gökyüzünde yağmuru yöneten bir varlıktır. Bu yüzden halk inancında tarım ve balıkçılığa bereket getiren kutsal bir hayvan olarak inanılmış ve Kore halkı için yağmur duası, ejderha kralı töreni ya da ejderha kralı duası gibi ritüellerde tapınıla gelen bir hayvan olmuştur. ${ }^{80}$ Ayrıca ejderha, yeryüzü ve gökyüzünde özgürce faaliyete geçebilme becerisine sahip olduğundan ülkeyi koruyan tanrı olarak ve kötülükleri kovup şans getiren ruh kovucusu olarak da tanınır. ${ }^{81}$ Ejderhanın bu özelliğini; öldükten sonra da ejderha olup ülkeyi korumak istediğini anlatan Şilla'nın 30. kralı Kral Munmu (문무왕, 661 681)'nun “호국룡설화 (Ülke koruyucusu ejderha hikayesi)”si oldukça meşhur bir efsanedir. Rivayete göre, Kral Munmu öldükten sonra deniz yoluyla Şilla'ya gelip Şilla halkına zulüm eden Japonlardan Şilla'yı koruyan bir ejderha olma dileğiyle kendisinin denize gömülmesini istemiş. Sonra kralın dileği gerçekleşince bir ejderha olup Japonya'dan Şilla'ya gelen deniz yollarını kapatıp sonra ise göğe çıktığı söylenilir. ${ }^{82}$

Ejderha rüyası, domuz rüyası ile birlikte hayırlı rüyalar olarak anılan iki rüyadan biri olup ülke ve yasaların koruyucusunu simgeleyen Kore'ye özgü

\footnotetext{
77 강민경, “遊仙文學에 나타난 道敉의 동물”, 51.

78 우연미, 성어 속 띠 동물의 상징의미 연구, 29-30.

79 한예민, 십이지 동물의 설화화 양상과 의미, 15.

80 이종관, "민화에 나타난 십이지동물", 357; 김수령, 중·한 관용어에 묘사된 $12 \square$ 동물, 61.

81 한예민, 십이지 동물의 설화화 양상과 의미, 16; 이종관, "민화에 나타난 십이지동물", 357; 강민경, “遊仙文學에 나타난 道敉의 동물”, 51 ; 우연미, 성어 속 띠 동물의 상징의미 연구, 33.

82 한국민족문화대백과, "문무왕 설화",

https://terms.naver.com/entry.nhn?docId=554634\&cid=46643\&categoryId=46643, (Erişim tarihi, 08 Mayis 2020).
} 
bir koruyucu tanrı sembolüdür. ${ }^{83} \mathrm{Bu}$ yüzden edebi yazıtlar, masal ya da halk biliminde ejderha, geleceği gösteren ruhani bir kâhin olarak sayg duyulur ve ülkeyi kuran ataları da simgeler ${ }^{84}$ Ejderha, hayali bir hayvan kavramindan ziyade daha gerçek gizeme ve doğaüstü yeteneklere sahip bir hayvan olarak sayısız fikir ve imaj oluşturmuştur. Hatta Doğu kültürünün hâkim olduğu yerlerde inançsal nesne ve sanatsal eser olarak topluluk zihniyeti içinde kök salmış bulunmaktadır. ${ }^{85}$ Geleneksel olarak Doğu Asya'da ejderha, kral ya da mühim birini simgeler. Şinsaimdang (신사임당)'1n İ Yulgok (이율곡)'a, Cong Mongcu (정몽주) annesinin Cong Mongcu'ya hamile kaldığında siyah renkli bir ejderha gördükleri rüyada veya ölüp sarı renkli ejderhaya dönüşerek Şilla'yı koruduğu söylenen kral Munmu Efsanesi(문무왕설화)'nde olduğu gibi hikâyelerde ejderha motifleri yer almaktadır. ${ }^{86}$

Ejderha ile ilgili deyim ya da atasözü "입신양명 (Başarılı olup adını duyurmak)" anlamını taşıyarak üstün ve seçkin birini simgeler ve böyle bir karakterin sahip olduğu yücelik sıfatı ya da gücü de ifade eder. “등용문(Ejderhanın uçma kapısı)" ifadesi genellikle zor bir yoldan geçerek başarılı olup adını duyurmak anlamını taşır. Yine "개천에서 용나다 (Nehirden ejderha çıkması)" ya da "용이 되다(Ejderha olmak)" ise, sıradan insanların büyük bir başarıya ulaşması veya önemli olmayan birinin başarılı olması gibi durumları da ifade eder. ${ }^{87}$ "여의주를 잃은 용 (Büyülü boncuğu kaybeden ejderha)" ifadesi ise önceki otorite veya gücünü kaybedip zavallı durumuna düşen birini kasteder. ${ }^{88}$

\section{6. Yılan Yılı ve Yılan Figürü}

Yılan yılı (뱀띠), 12 hayvanlı takvimde altıncı sırada yer alarak 1977, 1989, 2001, 2013 ve 2025 gibi senelerden oluşur. İnsanlık tarihinde yılan kadar dinsel törenlerde gizem anlamına gelen bir başka hayvan yoktur. Yılanın akla gelen görüntüsü insanlara zarar veren, aldatıcı, kötü, zehirli bir hayvan olmasının yanı sıra acı verici ve tehlikelidir. Aynı zamanda yılan cezbedici

\footnotetext{
83 김수령, 중·한 관용어에 묘사된 $12 \square$ 동물, 61.

84 리예, 한·중 12 띠 동물의 상징의미, 30.

85 이종관, "민화에 나타난 십이지동물", 350.

86 금영진, "흰색 십이지 동물 상징성", 53.

87 리예, 한·중 12 띠 동물의 상징의미, 33.

88 김수령, 중·한 관용어에 묘사된 $12 \square$ 동물, 63.
} 
şeytan, insanların aralarını bozan kurnaz kişiliktir ve soğukkanlılığı temsil eder. ${ }^{89}$

Yılanın nefret uyandıran varlığı, aynı zamanda kış uykusuna yatıp uyandığında derisini atma özelliğiyle ölümden her seferinde dirilip sonsuza kadar yaşayabilen ölümsüzlügün ve ebediyetin sembolüdür. ${ }^{90}$ Kişta yok olup ilkbaharda derisini yenileyerek gün yüzüne çıkan yılanın yaşam azmi, iyileşme, tekrar dirilme ve ebediyetin sembolü olmuştur. Bu düşünce yılanın erkeklerin cinsel gücünü arttıran bir yemek olmasını da sağlamıştır. ${ }^{91}$ Ayrıca çok sayıda yavrulaması açısından zenginlik, bolluk, bereket anlamlarına gelmektedir. Kore geleneksel halk inanışlarına göre yılan, evin bereketini arttıran önemli bir hayvan olarak kabul edilir. Ayrıca eskiden ev ve mahalleyi koruyan tanrı olarak tapılırd1..$^{92}$

Diğer taraftan yılanlar, zehirli ve iğrenç görünümleri, vücudundan daha büyük besinleri yutma alışkanlıkları ve çırpınan dilleri nedeniyle kötülük, açgözlülük ve ihaneti temsil eder. Bu nedenle yılanlar her türlü kötü, sinsi ve açgözlü varlıklar olarak deyimlerde betimlenmektedir. "속에 (능)구렁이가 들어있다 (İçinde bir yılan var) ${ }^{93 "}$ ifadesi, birinin çok sinsi olduğu anlamına gelir. Ayrıca "뱀을 잡다 (Yılanı tutmak)" deyimi, "Her halükarda zorluk ve felakete maruz kalacaktır" anlamını taşımaktadır. ${ }^{94}$

Bir de yılanların uzun ve kıvrılmış görünümü uzun şeyleri de sembolize etmek için kullanılır. Örneğin kalabalık insanların bulunduğu bir yerde sıraya girmek ve o sıranın uzunluğunu anlatmak için '장사진 (Canğsacin)95`veya '장사진을 치다 (Canğsacin kurmak)' deyimleri kullanılır.96 '용두사미(Yongdusami)' deyimi ejderhanın kafası yılanın kuyruğu anlamına gelerek, başlangıcı harika ancak sonu kötü biten şeyler için kullanılır. ${ }^{97}$ "굴에

\footnotetext{
89 김태영, 동물의 원형적 상징과 조형의식, 13.

90 이종관, "민화에 나타난 십이지동물", 357.

91 금영진, "흰색 십이지 동물 상징성", 55.

92 이종관, "민화에 나타난 십이지동물", 357.

93 "속에 (능)구렁이가 들어있다(içinde bir yılan var)" ifadesindeki '구렁이'kelimesi, yılan anlamına gelen diğer Korece'dir.

94 김수령, 중·한 관용어에 묘사된 $12 \square$ 동물, 68 ; 리예, 한·중 12띠 동물의 상징의미, 34.

95 장사진(Canğsacin)'ın anlamı uzun kuyruktur ve 장사진(Canğsacin) kelimesinin ortasındaki '

사() ' harfi yılan anlamına gelen Çincenin Korece yazılışıdır.

96 김수령, 중·한 관용어에 묘사된 $12 \square$ 동물, 71.

97 리예, 한·중 12 띠 동물의 상징의미, 34.
} 
든 뱀의 길이는 알 수 없다 (Delikte duran yılanın uzunluğu bilinmez)" atasözü, saklanan yetenek ve servetin miktarını ölçmenin zor olduğu anlamina gelir..$^{98}$

Yaşam ve ölüm, iyilik ve kötülük, bereket ve yoksulluk gibi olgulara etki eden yılanın gücü masallarda yılanın insan olarak kılık değiştirmesiyle ifade edilmektedir. Örneğin, "구렁덩덩 신선비 (Gureongdeongdeong Şinşeonbi)" ve "상사병으로 죽은 처녀 (Karasevdalı ötürü ölen kı)" masallarında yılan insan olarak kılık değiştirip kendisine iyilik yapana iyilik ile, kötülük yapana ise öcünü alarak karşılık vermektedir. ${ }^{99}$ Yılanın insana dönüşmesi, yılanın derisini çıartıp yeni bir hayatı elde edebilen bir varlık olduğunu yansıtmaktadır. ${ }^{100}$ Bunun dışında yılanın hızlı dil hareketleri yüzünden cazibenin şeytanı, insanların aralarını bozan varlık olarak simgeleştirilmektedir. So Cong $\mathrm{Cu}$ (서정주)'nun şiiri 'Hvasa (화사)'da da cazibeyle çırpınan yılanın dili tasvir edilmektedir. 'Hvasa', kelime olarak 'çiçek yılan' anlamına gelmektedir ve erkeği baştan çıkartan kadınlar için kullanılan mecazi anlam taşımaktadır. ${ }^{101}$

\section{7. At Y1lı ve At Figürü}

At y1l(말띠), 12 hayvanlı takvimde yedinci sirada yer alarak 1978, 1990, 2002, 2014 ve 2026 gibi senelerden oluşur. At, kutsal bir hayvan olarak simgelenir ve gökyüzünün elçisi, önderin doğumunun habercisi ve bilge bir kâhin olarak algılanır. ${ }^{102}$ At, canlılık, hayat dolu bir haraketlilik ve hızlı bir ivmeye sahip olarak olumlu bir anlam taşır. Atın canlılığı ve dinamikliği ölen kişinin ruhuna cennete doğru kılavuzluk yaparak gökyüzünün elçisi işlevini yapan bir hayvanı simgeler. Atın güçlü pozitifliğiyle kötü ruhu veya hastalığı kovarak mahalleyi koruyan koruyucu tanrı olduğuna inanılır. ${ }^{103}$ Atın kötü ruhu kovma yetkisine sahip olduğuna dair fikirler masallara da yansımaktadır. "말의 피를 무서워하는 도깨비 (Atın kanından korkan goblin)" masalında, her gece kötü bir goblin tarafından tacize uğrayan genç bir kadının atın başı ve kanıyla goblinden kurtulduğu hikaye

\footnotetext{
98 우연미, 성어 속 띠 동물의 상징의미 연구, 38.

99 한예민, 십이지 동물의 설화화 양상과 의미, 48-50.

100 한예민, 십이지 동물의 설화화 양상과 의미, 48-49.

101 박민영, “뱀과 달의 상상력- 서정주 시와 연구-“, 한국시학연구, 한국시학회, 35(2012, 12), 113114.

102 한예민, 십이지 동물의 설화화 양상과 의미, 16-17.

103 이종관, “민화에 나타난 십이지동물”, 357.
} 
içerilmektedir. ${ }^{104} \mathrm{Bu}$ hikayede goblinin en korktuğu şey, atın kanı olarak belirtilerek atın kötü ruhu kovma gücünü ortaya koymaktadır.

삼국유사 (Samkukyusa)'da Şilla'nın kurucusu 박혁거세 (Pak Hyeokgose)'nin yumurtadan çıktığında beyaz bir atın diz çökmüş secde ettiği içeriğine rastlanır. ${ }^{105} \mathrm{At}$, mitolojide ülkenin kurucu atasını ya da olağanüstü kişilerin doğumunu önceden haber verir, kral ya da generalin ölümüne delalet eder ve gökyüzünde uçan gizemli yetilere sahip olan bir varlık olarak görünür. ${ }^{106}$ Eski zamanlardan beri at, ilkel sanat, mezar sanatı, seramik, towoo (토우) ve duvar resimlerinde ortaya çıkar ve halk inancı ile halk kültürünün çeşitli konularında da görülür. Özellikle Kyongcu (경주) Çeonmaçong (천마총) ${ }^{107}$ mezarında gökyüzüne uçan beyaz bir atın çizildiği resim bulunmuştur. $\mathrm{Bu}$ da atlı towoo ya da Çeonmado (천마도)'nun mezarda gömülü olan kişinin ruhunu alıp göğe çıkarmasıyla atın inançlı ve büyülü bir simge olduğu anlaşılmaktadır. ${ }^{108}$ Ayrıca Coson Dönemi (조선시대, 1392 1910) 'nin kral mezarlarında yer alan at heykellerinin koruyucu vazifesini üstlenip kralın ordusu olarak otoriteyi ve koruyuculuğu simgeler. 109

Kore kültüründe at kutsal bir hayvan ve uğurlu bir hayvan olup, ölen kişinin ruhuyla mahallenin koruyucu tanrısının bindiği hayvan ya da general, damat, öncü gibi umut veren kişilerin bindiği hayvan olarak algılanır. ${ }^{110}$ Ayrıca atın eski çağ toplumunda savaşa giden general için gerekli bir araç olduğundan kahraman ya da devlet büyüklerinin binmesiyle asil veya yüksek mevkii de simgeler. Bir de uzun yola giderken ona binip gidildiği için seyahatin yoldaşı olarak da simgelenmiştir. ${ }^{111}$

\footnotetext{
104 한예민, 십이지 동물의 설화화 양상과 의미, 53.

105 일연, 삼국유사, 기이 제 1 권,"신라 시조 혁거세왕", 58.

106 금영진, “흰색 십이지 동물 상징성”, 57.

107 Şilla dönemi kralın mezarı. Mezarda gömülen atın eyerini örten örtün üzerine çizilen 'Çeonmado (gökyüzüne doğru uçan beyaz atın resmi)'un olduğu için Çeonmaçong denilir; 한국민족문화대백과, "경주 천마총 장니 천마도",

https://terms.naver.com/entry.nhn?docId=563072\&cid=46657\&categoryId=46657, (Erişim tarihi, 09 Mayis 2020).

108 김태영, 동물의 원형적 상징과 조형의식, 12.

109 김은선, “조선 왕릉 石獸연구“, 68.

110 황나현, 조선시대 동물화의 상징성, 40.

111 리예, 한·중 12 띠 동물의 상징의미, 35; 김수령, 중· 한 관용어에 묘사된 12 支동물, 74.
} 
Şair I Yuksa (이육사)'nın “Kırlar (광야)" adlı eserinde de beyaz ata binip gelen kurtarıcı görünür ve bu beyaz ata binip gelen kurtarıcı 'Kahraman (영웅)'a dair Kore halkının beklentisini temsil etmektedir ${ }^{112}$;

$$
\text { “다시 천고의 뒤에 }
$$

백마 타고 오는 초인이 있어

이 광야에서 목놓아 부르게 하리라

(Yine uzun yıllar ardından

Beyaz ata binip gelen olağanüstü bir insan olacak

Bu kırlarda yüksek sesle haykırır)" (이육사, "광야”)

Atın simgesinin anlamı olumlu, olumsuz ve nötr olarak çeşitli şekillerde ortaya çıkar ancak Kore deyimlerinde '인재 (Yetenekli kişi)' sembolü olarak ya da '빠르고 기세가 강하며 거칠 것이 없다 (Hızlı ve güçlü olup hiçbir eksiği yoktur)' anlamında ortaya çıkması göze çarpar. ${ }^{113}$ Mesela “천리마 (Bin mili koşan at)" 114 ise, olağanüstü bir at olup çok değerli insan anlamına gelir. “고삐 풀린 말 (Dizgini kopmuş at)" deyimi ise, hem özgürlüğ̈ü hem de aşırı özgürlüğe kaçarak kaba davranan insanları işaret eder. ${ }^{115}$ Ayrıca at, deyimlerde '무심하고 어리석다 (Düşüncesiz ve aptal)' anlamiyla da ortaya çıkar. Örneğin, '마이동풍 (Atın kulağına esen doğu rüzgârı)’sözü başkasının sözlerine kulak asmayıp es geçmek anlamını taşır. ${ }^{116}$ At, sert ve güçlü bir kuvvet ve büyük bir bedenle potansiyel olarak insana zarar verebilme yetisine de sahip olduğu için kötü insan, hırsız ya da acımasız insanlarla da karşılaştırılır. Örneğin, "마각이 드러나다 (Atın bacağının ortaya çıkması)" deyimi saklanılan kötü niyetin ortaya çıkması anlamını taşımaktadır. ${ }^{117}$

\footnotetext{
112 금영진, “한일 고전 빅 데이터를 이용한 오방색 십이지 동물 상징성 비교연구- 말을 중심으로-“, 동방학, $75(2019,4)$, 단국대학교 동양학연구원, 31.

113 김수령, 중 한 관용어에 묘사된 12支동물, 75.

114 천리마(Bin mili koşan at) kelimesindeki son harfi olan '마(馬)', at anlamına gelen Çincenin Korece yazılışıdır.

115 김수령, 중· 한 관용어에 묘사된 12 支동물, 76.

116 김수령, 중· 한 관용어에 묘사된 12 支동물, 79.

117 김수령, 중 한 관용어에 묘사된 12 支동물, 80 .
} 


\section{8. Koyun Yılı ve Koyun Figürü}

Koyun y1lı (양띠), 12 hayvanlı takvimde sekizinci sırada yer alarak 1979, 1991, 2003, 2015 ve 2027 gibi senelerden oluşur. Kore'de Üç Han Dönemi (M.Ö. 1. yüzyıl - M.S. 3. yüzyıl)'nde koyun etinin yemeklik olarak kullanıldığ1 söylense de hayvancllık Kore yaşamında pek yerleşmediği için günlük yaşamda koyunla ilgili örf ve âdet sembolü pek fazla yoktur. ${ }^{118}$

Koyun; saf, barış ve günah adağı, yani kurbanın simgesidir. ${ }^{119}$ Ayrıca koyun, mutlaka gittiği yoldan geri dönen inatçı ve dürüst bir karakteri olduğundan dürüstlük ve adaletin bir sembolüdür. ${ }^{120}$ Ancak bazen karakteri zayıf, cansız, pasif ve inatçı olarak da kabul edilir. ${ }^{121}$

Kurban olarak kullanılan koyun; masal, rüya, deyim ve atasözlerinde daima uysal, sabırlı ve şanslı alamet olarak kullanılır. Dolayısıyla Kore'de rüyada koyun görmek, servet, şans ve başarı getiren iyi ve şanslı rüyaların sembolü olarak yorumlanır. ${ }^{122}$ Deyimlerde koyun, çoğunlukla güçsüz ya da kurban sembolüyle ifade edilir. ${ }^{123}$ '희생양 (Kurban Koyunu)' sözü, başka insanların kazanç ya da hedefi uğruna hayatı, serveti, onuru ya da kazancı elinden alınan insanlar için mecazi anlamda kullanılır. "양의 탈을 쓰다 (Koyun derisi giymek)"atasözü, asıl karakteri vahşi olan birinin bunu saklamak için görünüşte iyi biriymiş gibi davrandığında kullanılır. ${ }^{124}$

Genellikle kurban sembolü olan koyun, bir masalda kötü ruhu kovma simgesi olarak anlatılmaktadır. "양의 가죽이 제일 무섭다 (En çok koyun derisinden korkarım)" adlı bir masal, bir mahalleyi korkutan devasa canavarın en çok korktuğu şeyin koyun derisi olduğunu öğrenerek koyun derisiyle yapılan kılıç kını ile canavarı öldürdügünü anlatır. ${ }^{125} \mathrm{Bu}$ masalda da koyunun bir kurban olarak adanma özelliği ile misale edilerek koyunun kötülüğü yok edebilme gücünü ima etmektedir.

\footnotetext{
118 김태영, 동물의 원형적 상징과 조형의식, 16.

119 한예민, 십이지 동물의 설화화 양상과 의미, 17; 리예, 한.중 12 띠 동물의 상징의미, 39.

120 김수령, 중· 한 관용어에 묘사된 12 支동물, 81.

121 리예, 한. 중 12 띠 동물의 상징의미, 39.

122 리예, 한.중 12 띠 동물의 상징의미, 39.

123 김수령, 중 한 관용어에 묘사된 12 支동물, 82.

124 김수령, 중 한 관용어에 묘사된 12 支동물, 83 ; 리예, 한 중 12 띠 동물의 상징의미, 40.

125 한예민, 십이지 동물의 설화화 양상과 의미, 54.
} 


\subsection{Maymun Yılı ve Maymun Figürü}

Maymun yılı (원숭이띠), 12 hayvanlı takvimde dokuzuncu sırada yer alarak 1980, 1992, 2004, 2016 ve 2028 gibi senelerden oluşur. Maymun insana en çok benzeyen hayvan olup hayvanların arasında en akıllı ve yetenekli sayılır. Ayrıca çocuğuna ve eşine bağlı olan sevgi ve şefkatini gösteren bir hayvandir. ${ }^{126}$

Sözlü olarak günümüze kadar gelen aktarımlarda maymun; yetenekli, taklitçi ve şımarık bir hayvan olarak sahneye çıkar. Kore geleneksel maskeli oyununda sahneye çıkan maymun, insanı acımasız ve samimice taklit eder. Hatta insanın ahlaksızlığını, hatalı davranışlarını hiciv eder ve insanları eleştirerek eğlendirir. Maymun, taklit ederek eleştirmeyi iyi yapmanın yanı sıra dogmatik ve tez canlı olduğu için rüyada belirirse, kıskanç insan, hilekar, oyuncu ya da dolandırıcı gibi olumsuz imaj ile yorumlanır. ${ }^{127}$ Bundan ötürü Kore halkının maymuna yansıyan imajı olumsuz düşünceleri gösterir. Kore atasözlerinde de aynen bu anlamda yer almaktadır. "원숭이도 나무에서 떨어진다 (Maymun da ağaçtan düşer)" ifadesi, her ne kadar yetenekli olursa olsun bazen hata yapılabileceğine dair bir anlam taşır. "원숭이 고기 재판하듯이 (Maymunun etini paylaşırmışçasına)" atasözü dıştan adaletliymiş gibi yapıp gerçekte kendi kazancını gözetmeyi ima ederek mecazi anlam taşır. ${ }^{128}$ Maymunun kahramanı olan bir masalda da maymun, kurnaz ve yalnızca kendini düşünen bencil karakter olarak betimlenmektedir. "원숭이와 게의 떡 싸움 (Maymun ile yengeç arasındaki pirinç keki kavgası)" adlı masalda yengecin yanına giden maymun, yengecin hazırladığı pirinç kekini tek başına yiyebilmek için keki alıp ağacın tepesine çıkar. Tam o sırada rüzgar esince, maymun yere düşer. $\mathrm{O}$ anda yengeç keki alıp deliğe girerek afiyetle yer. ${ }^{129}$

\subsection{Tavuk Yılı ve Tavuk Figürü}

Tavuk yılı (닭띠), 12 hayvanlı takvimde onuncu sirada yer alarak 1981, 1993, 2005, 2017 ve 2029 gibi senelerden oluşur. Tavuk, öterek sabah olduğunu ve ışığın doğduğunu haber veren bir hayvandır. Dolayısıyla halk arasında tavuk, karanlıktan sonraki aydınlığı bildiren uğurlu ve gizemli bir

\footnotetext{
126 김수령, 중· 한 관용어에 묘사된 12 支동물, 87.

127 김수령, 중 한 관용어에 묘사된 12 支동물, 87.

128 김수령, 중 한 관용어에 묘사된/2支동물, 88-89.

129 한예민, 십이지 동물의 설화화 양상과 의미, 55.
} 
hayvan olarak bilinir. Eski insanlar tavuk öttüğü zaman karanlığın gitmesiyle birlikte kötü ruhların gittiğine inandıkları için tavuğu doğaüstü güce sahip bir hayvan olarak algılamışlard.1.130

Tavuk yeryüzü ile gökyüzünde hareket edebilen bir varlık olduğundan farklı iki dünyanın ara bulucusu rolüyle efsanelerde yer alır. ${ }^{131}$ Tavuk yegane olarak Şilla kuruluş efsanesinde yer alır ancak anlamı ve önemi büyüktür. Şilla'nın Pakhyokgose efsanesine bakılırsa, Hyokgose kralının kraliçesi olan Alyong (알영)'un Gyeryong (계룡) ${ }^{132}$ un sol kaburgasında doğduğu, vücudunun bir kız çocuğu vücudu olduğu halde ağzının tavuk gagası şeklinde olduğu ve suda yıkadıktan sonra normal bir insan ağzına dönüştüğü söylenmektedir. ${ }^{133}$ Böyle efsanelerden de görülebildiği gibi sıra dışı birinin sahip olduğu bu özellikler, insan ve tavuğun bir araya gelerek oluşturduğu vücut ile açıklanmaktadır. ${ }^{134}$ Ayrıca Şilla kralı Alci (알지)'nin doğum habercisi görevini üstlenen de yine tavuktur. Günümüzde bilindiği gibi Gyongcu'nun Şirim (시림) adı, tavuk öttüğü için Gyerim (계림, tavuk ormanı) olarak değiştirilmiş̧tir. Bu açıdan tavuk, yeniliği ve başlangıcı bildiren bir hayvan olarak kabul edilir. ${ }^{135}$

Şilla kuruluş efsanesinde, tavuğun iyi haberleri getiren şansın işareti olduğu gibi masalda da bereketi getiren uğurlu haberci olarak betimlenmektedir. “닭소리 나는 명당 (Tavuğun ötme sesi duyulan yer, en güzel yer)" masalında, bir adamın tarlada uyuya kaldığında tavuğun öttüğü sesi işitip o yeri ebeveynleri için mezarlık olarak kullandıktan sonra çok zengin olduğunu söyler. ${ }^{136}$

Kore kültüründe yeni yılda tavuk, ejderha ve kaplan resimlerini evin ana kapısına asma âdeti vardı ve bunun sebebi tavuğun hayaletleri kovma yeteneği olduğuna inanılmasıydı. Dolayısıyla tavuk, evde bir şölen, düğün ve yeni yıl kutlamasında yemek olarak da sunulurdu. ${ }^{137}$ Horoz ise mertliğin ve

\footnotetext{
130 이종관, “민화에 나타난 십이지동물”, 357; 한예민, 십이지 동물의 설화화 양상과 의미, 56-57.

131 이현주, 신라의 건국신화와 동물 상징, 25.

${ }_{132}$ Tavuk ile ejderhanın birleşiminden oluşan hayali bir hayvan.

133 일연, 삼국유사, 기이 제 1 권, "신라 시조 혁거세왕', 59.

134 염미란, “신라 토우에 관한 연구“, 관대논문집, 카톨릭 관동대학교, 1996, 388; 김정숙, “新羅文化 에 나타나는 動物의 象徵-《三國史記》 新羅本紀를 중심으로-“, 신라문화, 7(1990, 12), 동국대학교 신라문화연구소, 82.

135 김종대, “動物을 통해본 民俗象徵”, 172.

136 한예민, 십이지 동물의 설화화 양상과 의미, 57.

137 김태영, 동물의 원형적 상징과 조형의식, 21; 김종대, “動物을 통해본 民俗象徵” 172.
} 
yiğitliğin simgesi olarak ideal bir erkek imajını simgeler. Konfüçyüsçülük açısından tavuğun kafasındaki ibik sanki yüksek rütbeli memurun şapkası gibi göründüğünden bilim insanı işareti olmasının yanı sıra başarılı olma, zenginlik ve şöhretin simgesi haline gelmiştir. ${ }^{138}$

Tavuğa dair ilk olarak akıllara gelen şey, öterek sabah olduğunu bildiren bir varlık olmasıdır. Dolayısıyla "첫 닭이 울다 (Horozun ilk ötmesi)" ifadesi sabah olduğu anlamına gelir. ${ }^{139}$ Fakat horozun ötmesinin aydınlık ve ışığı haber veren olumlu bir anlamı olmasının tersine tavuğun ötmesi olumsuz bir anlama gelir. "암탉이 울다 (Tavuk ötüyor)" ifadesi kadının sözünün kocasından daha güçlü ve değerli olduğu anlamına gelir ve "암탉이 울면 집안이 망한다 (Tavuk öterse yuva yıkılır)" atasözü, ailede erkeğin otoritesi ve konumunun daha yüksek olması gerektiğini ima eder. ${ }^{140}$ Diğer yandan tavuğun vücudu küçük ve zayıf olduğundan deyim veya atasözlerinde de güçsüz ve ürkek anlamına gelir. Özellikle civciv ya da yumurta daha da zayıf kimse anlamına gelir. "달걀로 바위 치기 (Yumurta ile kayaya vurmak)" atasözü dirense de ne olursa olsun yenemeyeceğini anlatan bir durumun mecazi ifadesidir. '닭대가리 (Tavuk kafalı)' sözü ise, kuş beyinli anlamını içererek aptal veya akılsız insanları ifade eder. ${ }^{141}$

\subsection{Köpek Yılı ve Köpek Figürü}

Köpek yılı (개띠), 12 hayvanlı takvimde on birinci sırada yer alarak 1982, 1994, 2006, 2018 ve 2030 gibi senelerden oluşur. Köpek, at ve inek gibi insanoğluna en yakın hayvandır. Kore kültüründe köpek sadakat ve nezaketin simgesi, bazen de aşağılama ve zavallılı̆̆ın simgesi olarak iki statüde yer almaktadır. Çok uzun yıllar insanlarla beraber yaşayan köpekler sorgusuz sualsiz insanlara kendini adayan sadakatin simgesidir. ${ }^{142} \mathrm{Bu}$ yüzden köpekler genellikle masallarda sadık, vefalı ve dürüst hayvan olarak betimlenir. Mesela "개와 고양이가 구슬을 찾은 이야기 (Köpek ve kedinin birlikte mücevher boncuğunu bulduğu hikayesi)" masalında, köpek ve kedinin yaşadığı evde bir hırsız gelip ev sahibinin çok değerli boncuğunu çalar. Zor duruma düşen ev sahibine yardım etmek için iki hayvan yola çıkıp

\footnotetext{
138 김태영, 동물의 원형적 상징과 조형의식, 22 ; 황나현, 조선시대 동물화의 상징성, 8.

139 김수령, 중· 한 관용어에 묘사된 12 支동물, 93.

140 김종대, “動物을 통해본 民俗象徵”, 173.

141 김수령, 중· 한 관용어에 묘사된/ 12 支동물, 95; 리예, 한 중 12 띠 동물의 상징의미, 44-45.

142 황나현, 조선시대 동물화의 상징성, 24.
} 
her zorluğu aşarak sonunda boncuğu bulup ev sahibine geri getirir. ${ }^{143} \mathrm{Bu}$ hikâyede köpek ile kedi ev sahibinin iyiliğe sadakat ile karşılığı verir.

Halk arasında köpeğin kötü ruhları kovma yeteneğine sahip bir hayvan olarak bilinmesi, köpeklerin koku ve duyma yetileri hassas olduğu için ufacık bir kokuyu alıp ufacık bir hareketi dahi kaçırmamasından kaynaklanmaktadır. Bir de Şamanizm'de köpeğin bu dünya ile öbür dünya arasında bir elçi olarak kılavuzluk ettiği düşünülür. ${ }^{144}$

Buna rağmen köpek, aşağılamanın simgesi olarak atasözleri ve küfürlerde kullanılır. Kore'de küfürlerin birçoğu köpek ile bağlantılıdır ve ismin önüne '개 (Köpek)' konulduğunda aşağılık ve düşük seviyeli nesne haline gelir. Örneğin, 개살구 (Köpek kayısısı), 개꿈 (Köpek rüyası), 개떡 (Köpek keki), 개죽음 (Köpek ölümü) gibi kelimelerin iyi olmayan, değersiz ve boş şeyler olduğunu ima eder. ${ }^{145}$

İnsanlar sahibine vefalı olup iyiliğinin karşılığını ödemeyi bilen akıllı köpekleri sevseler de, diğer yandan utanç ve hor görme muhatabı olarak köpeği alçak ve sıradan şeyler ile karşılaştırırken genellikle kinayeli bir şekilde konuşurlar. Böylece köpekler, Kore kültüründe vefa ve sadakatin devamı, koruma, rehberlik, insanın yol arkadaşı gibi simgesel anlamlarla birlikte aşağılamanın temsilcisi olarak zıt iki imaj sergiler. ${ }^{146}$

Kore deyimlerinde '비천하고 하찮다 (aşağı ve önemsiz)' anlamına gelen köpek kelimesinin simgesel anlamı bariz bir şekilde çıkar ve deyimlerde sembolik anlamlarının neredeyse hepsi olumsuzdur. '개똥 (Köpek dışkısı)' lafı değersiz ve önemsiz bir şey anlamına gelir. "개뿔도 아니다 (Köpek boynuzu dahi değil)" ifadesi özellikle öne çıkan bir özelliği yok anlamına gelir. "개똥도 약에 쓰려면 없다 (Köpek dişkısı da ilaç olsa bulunmaz)" atasözü de her yerde yaygın olan köpek dışkısının bile lazım olduğunda bulunmasının zor olduğu anlamına gelerek değersiz bir şey de aradığında ortada bulunmasının zor olduğunu ima eder. “달 보고 짖는 개 (Ay'a bakıp havlayan köpek)" deyimi karşıdakinin durumunu bilmeden akılsızca konuşan insanları işaret eder. “푸줏간 강아지 (Kasap köpek yavrusu)” ifadesi

\footnotetext{
143 한예민, 십이지 동물의 설화화 양상과 의미, 60-61.

144 한예민, 십이지 동물의 설화화 양상과 의미, 18; 이종관, “민화에 나타난 십이지동물", 358

145 김수령, 중 한 관용어에 묘사된 12 支동물, 99.

146 리예, 한 중 12 띠 동물의 상징의미, 46-47; 김정진, “카프카의 문학 작품에 나타난 동물군상”, 265-

266 ; 김수령, 중· 한 관용어에 묘사된 12 支동물, 99.
} 
de cahil ve korkusuzca kendini ortaya atan insanlar için kullanılır. ${ }^{147}$ "닭 쫓던 개 지붕 쳐다본다(Tavuk kovalayan köpek dama bakar)" atasözü ise, çok emek verdiği halde başarısızlıkla sonuçlanan bir iş karşısında şaşkınlık ve utanç duymayı gösteren bir ifadedir. ${ }^{148}$

\subsection{Domuz Yılı ve Domuz Figürü}

Domuz yılı (돼지띠), 12 hayvanlı takvimde on ikinci sırada yer alarak 1983, 1995, 2007, 2019 ve 2031 gibi senelerden oluşur. Kore' de domuz çok eskilerden beri ataları anma törenlerinde ve dini törenlerde kurban olarak kullanılmıştır. Günümüzde de 'Gut (굿)' denilen şaman ayinlerinde de sıkça kullanıldı ̆̆ görülmektedir.

Şanslı hayvan olarak kabul edilen domuzlar eski metinlerde de tılsımlı simge olarak görülür. Zenginlik ve bereketin kaynağı olarak ailenin koruyucusu ve bolluk tanrısını sembolize eder. ${ }^{149} \mathrm{Bu}$ yüzden Ocak ayının başında dükkân sahipleri dükkânlarını açarken domuz resmini tılsım olarak asmışlardı. Bir de rüyada domuz görmek, çok güzel bir şansın ve zenginliğin geleceği anlamına geldiğinden günümüzde de Koreliler rüyalarında domuz gördüklerinde piyango bileti alırlar. Rüyalarında bir domuz eve girerse ya da domuzun ardından gidilirse şansın geleceğine inanılır. ${ }^{150}$

Domuzların zenginlikle ilişkili olmasının nedeni, domuzların temel geçim kaynağı olması ve Çince '豚 (돈, domuz)' kelimesinin Korece para anlamına gelen '돈(para)' kelimesi ile aynı seslendiriliyor olmasıdır. Domuzlar aynı zamanda sık doğurganlıkları nedeniyle bereket ve refah simgesi olarak kabul edilmektedir. ${ }^{151}$ Genelde dişi domuz ile etrafında çok yavrusu olan resimler, işlerin büyümesi ve servetin çoğalmasının arzu edildiğini gösterir. ${ }^{152}$ Kore' de yaygın olan halk inanışına göre, özellikle 'Sarı domuz yılı(황금돼지해)'nda doğan kişinin bolluk ve bereket açısında şanslı olduğuna inanılmaktadır. Dolayısıyla geçen domuz yılı olan 2007'te Kore'de doğum oranı oldukça yükselmiştir. ${ }^{153}$

\footnotetext{
147 김수령, 중· 한 관용어에 묘사된/12하동물, 99- 100, 104-106.

148 우연미, 성어 속 띠 동물의 상징의미 연구, 55.

149 김수령, 중 한 관용어에 묘사된 12 支동물, 107; 한예민, 십이지 동물의 설화화 양상과 의미, 19.

150 한예민, 십이지 동물의 설화화 양상과 의미, 63-64.

151 이종관, “민화에 나타난 십이지동물”, 358; 리예, 한·중 12 띠 동물의 상징의미, 51.

152 이종관, "민화에 나타난 십이지동물", 352.

${ }^{153}$ Sarı domuz yılı olarak bilinen 2007 yılında Kore' de yeni doğan bebek sayısı önceki seneye göre 45,ooo kişi artmış ve doğum oranı da 1.25 kişi olarak yükselmiştir. Tabi ki ertesi yılda doğum
} 
Buna mukabil aynı zamanda domuzlar, atasözlerinde veya masallarda dağınık, açgözlü, kirli, tembel ve aptal hayvanlar olarak geçmektedir. ${ }^{154}$ Mesela, "개와 돼지 (Köpek ve domuz)" adlı masalda domuz, ev sahibinin kendisinden daha çok köpeği sevdiğini hisseder ve bir gün köpeğe sebebini sorar. Köpek de kendisinin gece gündüz eve göz kulak olarak evi hırsızdan koruduğunu, domuzun ise bütün gün yem yiyip uyuduğunu söyler. Bunu duyan domuz, ev sahibinden sevilmesi için geceler durmadan 'kkul kkul kkul (꿀꿀꿀)' sesleri çıkartarak kendince evi için çalışmakta olduğunu gösterir, fakat bu evdekileri çok rahatsız eder. Bunun neticesinde domuzun ani gürültülerinden rahatsız olan ev sahibi pazarda domuzu satar. ${ }^{155}$ Bu hikaye, domuzun düşüncesizliğini ve aptallığı yansitır.

Kore halkı domuzları bereket getiren şanslı bir hayvan olarak kabul etmişse de, domuzların günlük hareketlerine bakarak yaptıkları açgözlülük, tembellik ve kirlilik, domuzların ana sembolleri haline gelmiştir. Özellikle, günlük konuşmalarda bir kişi domuza benzetildiği zaman aşağılamak amaçlı olarak kullanılır. Domuz kelimesinin kullanıldığı bu tür ifadeler ya da küfürler atasözleri haline gelmiştir ve kötü eylemlerde bulunanları azarlamak için kullanılır. Örneklere bakıldığında, “돼지같은 욕심 (Domuz gibi açgözlülügü̈)" ve "돼지같이 먹고 소같이 일한다 (Domuz gibi yiyip sığır gibi çalışmak)" gibi ifadeler domuzun kötü yönünü ifade eden atasözleridir. Bir de "산돼지 잡으려다 집돼지 잃는다 (Yabani domuzu yakalarken evdeki domuzu elinden kaçırır)" atasözü, aşırı açgözlü olursa elindeki de kaybedecek uyarını taşımaktadır. "돼지도 낮을 붉히겠다 (Domuzun yüzü bile kızarır)" atasözü ise, utanmazlı̆̆ı bilmeyen insanı eleştiren ifadedir. “돼지 꼬리 잡고 순대 달란다 (Domuzun kuyruğunu yakalayan mumbar dolmasını ister)" atasözü de hem hırslı hem de acele bir şey elde etme arzusunu tasvir eden betimlemedir. ${ }^{156}$ Ayrica "돼지 왼 발톱 (Domuzun sol ayak tırnağı)" atasözü, doğru yoldan çıkıp yanlış yolla iş yapması ya da diğer

\footnotetext{
oranı düşmüştür. Ancak aslında bolluğu getirdiğine inanılan sarı domuz yılı 2007 yılı değil, 2019 yılı olmuştur; 금영진, “한일 고전 빅 데이터를 이용한 오방색 십이지”, 25.

154 김수령, 중'한 관용어에 묘사된/ 12 支동물, 107.

155 굿뉴스데일리, "개와 돼지”, http://www.gndaily.kr/news/articleView.html?idxno=30873, (Erişim tarihi, 09 Mayıs 2020).

156 시선뉴스, “돼지와 관련된 속담",

http://www.sisunnews.co.kr/news/articleView.html?idxno=121807, (Erişim tarihi, 09 Mayıs 2020).
} 
insanlardan çok farklı davranışta bulunanları ima eden mecazi ifadedir. ${ }^{157}$ “돼지 목에 진주 목걸이 (Domuzun boynunda inci kolye)” atasözü ise, saçma bir davranışta bulunanlar ya da bir şeyin değerini bilmeyenler için kullanılmaktadır.

Buradaki birkaç örneklerde görüldüğü gibi, genellikle domuz, deyimler ya da atasözlerinde negatif anlamda kullanılır. Yine de gerçekte tarım hayatında sığır ve domuzlar servet olarak değer kazandığından dolayı malı simgeler. “돼지꿈을 꾸다 (Rüyada domuz gördüm)” ifadesi, domuzun mal mülk şans getiren bir hayvan olduğunu ima eder. ${ }^{158} \mathrm{Bu}$ nedenle domuz, Kore kültüründe hem olumlu hem de birçok anlamda olumsuz olarak bir zıtlık içerisinde anlamlandırılan bir hayvandır. ${ }^{159}$

\section{Sonuç}

Hayvanlara yüklenen sembolik anlamlar, genel olarak ortak bir görüş taşır. Ancak ülke ve ulusa göre, bazen o anki ihtiyaç ve dönemsel anlamda karmaşık, çok yönlü ve bazen oldukça farklı bir sembol olarak da ortaya çıkmaktadır. Bu yüzden hayvan motifleri analiz edilirken sadece barındırdıkları sembolik anlamları algılamakla kalmayıp onda yansitılan toplum durumu da anlamak gerekir. Dolayısıyla hayvan sembolleri, Korelilerin hayal gücünü, anlayışını ve algılama yeteneğinin birleşmesinden oluşan Kore kültürüne dair bir özet olduğu varsayılmaktadır.

$\mathrm{Bu}$ çalışmada incelendiği gibi Kore'de hayvanlar petroglifler, mezar duvarı resimleri, towoo (토우), heykeller, halk resmi gibi çeşitli alanda şekillendirilmiştir. Bunların dışında da hayvanlar masal, halk inanışı, atasözleri, edebi eserler, rüyalar, mevsimsel gelenekler ve halk oyunlarında yer alıp kişileştirilerek ya da betimlenerek kullanıla gelmiştir. Dolayısıyla hayvanların içerdiği çeşitli simgeler, Korelilerin özgün hislerini ve kişisel özelliklerini yansıtmaktadır. Ayrıca Korelilerin doğum yıllarını belirten 12 hayvanlı takviminde yer alan 12 hayvanın anlamı ve sembolleri, Kore ulusunun his ve düşüncelerini aktaran atasözü ve deyimlerde sıklıkla kullanıldığı gibi Korelilerin günlük yaşamını da etkilemiştir. Bu yüzden Kore'de hayvan anlayışı Kore kültürünü oluşturan bir unsur olarak yer almıştır.

\footnotetext{
${ }^{157} \mathrm{KBS}$ WORLD RADIO, “돼지 관련 속담”,

http://world.kbs.co.kr/service/contents_view.htm?lang=k\&board_seq=363221, (Erişim tarihi, 09 Mayis 2020).

158 김수령, 중· 한 관용어에 묘사된 12 支동물, s. 109-110; 리예, 한·중 12 띠 동물의 상징의미, 51-52.

159 이종관, “민화에 나타난 십이지동물”, 352.
} 
Bu çalışmada belirlendiği gibi Kore folklorunda evcil hayvanlar genelde varlık, statü ve huzur getiren hayvanlar olarak görülmüştür. Vahşi hayvanlar ise, genellikle kötü ruhları kovma gücünü taşımakla birlikte uzun zamandır insanların yüreğinde özel bir sembolik anlam oluşturmuştur. Örneğin Kore kültüründe fare, yılan, domuz gibi hayvanlar, bolluk, bereket ve zenginliği simgelemektedir. Ayrıca bu hayvanlar sadece zenginliği temsil etmekle kalmayıp zamanla inançsal varlıklar olarak da Kore kültüründe yer edinmiştir. Özellikle domuz Kore halk inanışında 'varlık ve şans' tılsımı olarak yerleşmiş olup, adeta zenginliğin bir muskası haline gelmiştir. $\mathrm{Bu}$ yüzden iş yerleri veya yılbaşında evlerin giriş kapısı ya da duvarlarında domuz resimler asılırdı. Halen bu anlayış Kore kültüründe ektiyi sürdürerek, domuz yılında yeni bebek doğum oranının artması, yeni işlerin açılış törenlerinde domuzun başı konulması ve rüyasında domuz görenlerin piyango satın alması gibi görüntüler sergilenmektedir. Sığırlar gayretle çalışan ve sahibine itaat eden iyi bir hayvan olarak kabul gördüğünden, güvenilir kişiliği ve sadakatin bir sembolü olmuştur. Bu yüzden Kore'de siyasetçilerin siyasi propagandasında “여러분의 소같이 우직한 일꾼이 되겠습니다 (Sizin için sığır gibi sadakatli uşağınız olacağım)"ifadesi, sıklıkla ifade edilmektedir. Kore kültüründe koyunlar, genelde doğası gereği güçsüz ve nezaket özelliği taşıdığından dolayı başkasının menfaat uğruna kurban edilen '희생양 (fedakâr Kurban)'ı sembolize eder. Tavşan ise özellikle olağanüstü zekiliği sembolize eder. Ancak maymun ise, yetenekli kişiliği simgeleyerek daha bencil açıdan kendi çıkarı için kullanılan kurnazlığı sembolize eder.

Diğer taraftan kaplan dağda yaşayan kutsal bir hayvan ve dağın koruyucusu olarak algılandığından, sıkça bir koruyucu olarak kral mezarları ya da kulelerde kaplan heykeli dikilmiştir. Ayrıca kaplan mutlak otorite ve gücü temsil ederek yiğitlik, şeref, kuvvet ve askerlerin cesurluğu gibi kültürel anlamları da barındırır ki, Kore'nin dünyaca ev sahipliği yaptığı 1988 Seul Olimpiyatları ve 2018 Pyongçang Kış Olimpiyatları'nda Kore ulusun özünü temsil eden maskot olarak kullanılmıştır.

Ejder, at ve tavuk ise, doğaüstü dünya ile iletişim kurabilen gizemli bir hayvan sembolü ve geleceğe dair iyi bir işaret olarak kuruluş efsaneleri ya da mitlerde motif edilmiştir. Genelde şafağı bildiren horozun ötmesi bir umudun simgesi olarak, at ise genellikle değerli insanın bindiği araç olarak onun gelişini bildiren iyi işaretli bir haberci olarak bir ulus için yeni sayfayı açacak bir kahraman ya da kurtarıcının bir sembolü olmuştur. Özellikle mit ya da efsanelerde yer alan hayali hayvan olan ejderha, ideal bir yaşam hakkındaki insanların arzularını yansıtarak hem mutlak otoriteyi temsil eder hem de her 
zorluklardan geçerek zirveye ulaşan başarıyı ima eder. Dolayısıyla Kore kültüründe "용꿈을 꾸다 (Rüyada ejderha görmek)"deyimi, başarıya giden şans anlamını taşır.

Hayvanların motifleri, insanların duygu ya da içine düştükleri durumlar gibi soyut kavramları ayrıntılı ve somut bir şekilde gösteren bir araç olarak gerçekçi ve canlı olup doğrudan iletim etkisi oluşturmuştur. Özellikle Kore atasözlerinde yer alan hayvanların olumsuz sembolik anlamları ya da renkleri, hayvanların gerçek şekilleri, özellikleri ve karakterleri hakkındaki genel algıyı olduğu gibi yansıtmıştır. Mesela Kore halk inanışında bolluk ve bereketin sembolü olan fare, yılan, domuz gibi hayvanların günlük yaşamında sıkça kullanılan deyimler ya da atasözlerinde olumlu anlamlardan daha ziyade olumsuz yönde kullanımları göze çarpmaktadır. Ayrıca insanlar ile samimi ilişki içinde yaşayarak özel bağ kurmuş olan köpekler, insanlara yakın olmasına rağmen, Kore kültüründe farklı anlayış göstermektedir. Kore'de deyimler ya da atasözlerinde kullanılan köpek ile alakalı ifadeler, genellikle değersiz, aşağılayıcı ve hakaret anlamı taşır. Korelilerin günlük yaşamında çokça kullanılan '개뿔 (Köpek boynuzu)' veya '개똥 (Köpek dışkısı)' ifadeleri hiç ve değersiz anlamına gelir hatta '개같은 인간 (Köpek gibi bir insan)' ifadesi ise, tamamen aşağılayıcı küfürlere dönüşür. Aynı şekilde '생쥐같은 녀석 (küçücük fare gibi herif)'deyimi, her kötü işleri işlenip kurnazca suçtan kaçan kişi ya da haini ima eder. '뱀같은 인간 (Yllan gibi bir adam)' ifadesi, zehir gibi insanlara ve topluma zarar veren adamı işaret eder. Ayrıca Kore kültüründe domuzun varlık ve zenginliğin bir tılsımı olduğu halde, atasözlerinde kullanılan domuzun imajı daha çok açgözlülük, ahmak ve saçmalık anlamına gelmektedir. 


\section{Kaynakça}

강민경, “遊仙文學에 나타난 道敉의 동물에 대한 형상과 인식”, 동방한문학, 62(2015),

동방한문학회, 31-60.

(KANG, Min-kyoung, "Yusun Edebiyat Kitabında Yer Alan On iki Hayvan İmgeleri ve Tanımı",

Doğu Çin Edebiyatı, Sayı 62 (2015), Doğu Çin Edebiyatı Derneği, s. 31-60.)

굿뉴스데일리, "개와 돼지” (Goodnews Daily, "Köpek ve Domuz"),

http://www.gndaily.kr/news/articleView.html?idxno=30873, (Erişim tarihi, 09 Mayıs 2020).

금영진, “한일 고전 빅 데이터를 이용한 오방색 십이지 동물 상징성 비교연구- 말을 중심으로-“,

동방학, $75(2019,4)$, 단국대학교 동양학연구원, 23-49.

(KEUM, Young-Jin, “Kore-Japon Klasik Büyük Verilerini Kullanarak Beş Renkli Zodyak

Sembolizminin Karşılaştırılması - At Merkezli-", Doğu Araştırmaları, Sayı 75(2019, 4),

Dankook Üniversitesi Doğu Araştırmaları Enstitüsü, s. 23-49.)

금영진, “흰색 십이지 동물 상징성의 한일비교", 동방학, $66(2017,1)$, 단국대학교 동양학연구원, 4372.

(KEUM, Young-Jin, "Kore ve Japon Klasik Edebiyatının On İki Kutsal İşaretli Beyaz Hayvanlarının Sembolizmi Üzerine Karşılaştırmalı Bir Çalışma", Doğu Araştırmaları, Sayı 66(2017, 1), Dankook Üniversitesi Doğu Araştırmaları Enstitüsü, s. 43- 72.)

김미- 전영근, "십장생의 문화적 상징의미”, 중국조선어문, 1(2012), 길림성민족사무위원회, 12-18. (KIM, Mi- JONON, Young-Geun, "On Uzun Ömürün Kültürel Sembolleri", Çin, Kore Dili Çalışmaları, Sayı 1(2012), Gilrimsung Ulusal İşler Komitesi, s. 12-18.)

김수령, 중 한 관용어에 묘사된12촏ㄷㅇㅁ물의 상징의미 비교 연구, 석사논문, 부산외국어대학교, 2011. (KIM, Soo-Ryung, Çin ve Kore Deyimlerinde On İki Hayvanın Sembolik Anlamı Üzerine Karşılaştırmalı Bir Çalışma, Yüksek Lisans Tezi, Pusan Yabancı Üniversitesi, 2011.)

김은선, “조선 왕릉 石獸연구“, 미술사학연구, $283 \cdot 284$ (2014,12), 55-82.

(KIM, Eun-Sun, “Joseon Hanedanlığı Kraliyet Mezarlarında Taş Hayvan Heykelleri”, Sanat Tarihi Araştırmaları, Sayı $283 \cdot 284$ (2014,12), s. 55-82.)

김정숙, “新羅文化에 나타나는 動物의 象徵-《三國史記》 新羅本紀를 중심으로-“, 신라문화, 7(1990, 12), 동국대학교 신라문화연구소, 69-104.

(KIMM, Jeong-Sook, "Silla Kültüründe Hayvan Sembolleri Üzerine- <<Samkuksagi >> Şillabongi Merkezli-", Silla Kültürü̈ Araştırma Enstitüsü Dergisi, Sayı 7(1990, 12), Silla Kültürü Araştırma Merkezi Dongguk Üniversitesi, s. 69-104.)

김정은, "십장생도의 상징과 생명사상", 한국민화, 6(2015), 한국민화학회, 6-40.

(KIM, Jung-Eun, "<On Ömür Simgesi Resim> ve Yaşam Düşüncesi Sembolleri Üzerine Bir Çalışma", Kore Folklor Resim, Sayı 6(2015), Kore Halk Resim Çalışmaları Derneği, s. 6-40.)

김정진, “카프카의 문학 작품에 나타난 동물군상의 상징적 의의", 카프카연구, $1(1984,6)$, 카프카학회, 248-288.

(Kì, Jeong-Jin, "Kafka'nın Edebi Eserlerinde Hayvanın Sembolik Anlamı," Kafka Araştırma, Sayı 1 (1984, 6), Kafka Topluluğu, s. 248-288.)

김종대, “動物을 통해본 民俗象徵과 意味에 대한 한 考察”, 민속학연구, 8(2001), 국립민속박물관, 153-182.

(KIM, Jong-Dae, "Halk Sembolleri ve Hayvanların Anlamı Üzerine Bir Düşünce", Kore Halk Araştırmaları Dergisi, Sayı 8(2001), Kore Ulusal Halk Müzesi, s. 153-182.)

김태영, 동물의 원형적 상징과 조형의식 -원시 신앙과 관련된 동물을 중심으로-, 석사논문, 국민대학교, 2005. 
(KIM, Tae-Young, Hayvanların Sembolik Estetik Bilincinin Araştırılması - İlkel Dinle İlgili Hayvan Merkezli-, Yüksek Lisans Tezi, Kookmin Üniversitesi, 2005.)

두산백과, “풍수지리설" (Doosan Ansiklopedisi, "Feng Shui Coğrafyası"),

https://terms.naver.com/entry.nhn?docId=1159140\&cid=40942\&categoryId=31445,

(Giriş tarihi, 06 Mayıs 2020).

리예, 한 중 12 띠 동물의 상징의미 대조를 통한 한국어 교육용 관용어 연구, 석사논문, 중앙대학교, 2018.

(Lİ, Ye, Korece ve Çince 12 Zodyak Sembolik Anlam Karşıtlı̆̆ı Olan Kore Deyimleri Öğretimi Üzerine Bir Araştırma, Yüksek Lisans Tezi, Chungang Üniversitesi, 2018.)

박민영, “뱀과 달의 상상력- 서정주 시와 연구-“, 한국시학연구, 한국시학회, 35(2012, 12), 101-139.

(PARK, Min-Young, “Bir Yılan ve Ayın Hayal Gücü: Seo Jeong-ju Şiirleri, Bir Çiçek Yılanı ve Kış Gökyüzü Üzerine Bir Araştırma", Kore Şiir Araştırmaları, Kore Şiir Araştırmaları Derneği, Sayı 35(2012, 12), s. 101-139.)

송영숙, "한일 십이지 동물설화의 비교연구- 쥐 모티프의 상징을 중심으로-", 한국일본어문학회 학술발표대회논문집, 한국일본어문학회, 2008, 383-388.

(SONG, Young-Sook, "Kore-Japon On İki Hayvan Hikayesi Karşılaştırmalı Bir Çalışma- Fare Motifinin Sembolü Üzerine-", Kore-Japon Edebiyat Derneği Konferans Sunumları, Kore Japon Edebiyatı Derneği, 2008, s. 383-388.)

송영숙, “한일 토끼 설화의 비교 연구- 트릭스터의 유형을 중심으로-“, 일본문화학보, $69(2016,5)$, 일본문화학회, 275-294.

(SONG, Young-Sook, "Kore ve Japon Tavşan Masallarının Karşılaştırmalı Çalışması Düzenbazlık Üzerine", Japon Kültür Dergisi, Sayı 69(2016, 5), Kore- Japon Kültür Derneği (Jcak), s. 275-294.)

시선뉴스, “돼지와 관련된 속담"(Sisunnews, "Domuz ile İlgili Atasözü"),

http://www.sisunnews.co.kr/news/articleView.html?idxno=121807, (Erişim tarihi, 09 Mayıs 2020).

염미란, "신라 토우에 관한 연구“, 관대논문집, 카톨릭 관동대학교, 1996, 381-400.

(YEOM, Mi-Ran, "Silla Hanedanlığı Dönemi Hayvan Figürleri(Towoo) Üzerine Araştırma ", Kwandong Üniversitesi Sempozyumu, Katolik Kwandong Üniversitesi, 1996, s. 381-400.)

우연미, 성어 속띠 동물의 상징의미 연구, 석사논문, 강원대학교, 2008.

(WOO, Yen-Mi, Zodyak Hayvanların Deyimlerdeki Sembolik Anlamı Üzerine Bir Araştırma, Yüksek Lisans Tezi, Kangwon Üniversitesi, 2008.)

이유진, 새의 이야기를 담은 장신구, 석사논문, 국민대학교, 2011.

(LEE, Yu-Jin, Kuş Temalı Mücevher Takı Üzerine Bir Çalışma, Yüksek Lisans Tezi, Kookmin Üniversitesi, 2011.)

이종관, "민화에 나타난 십이지동물의 민속의식에 관한 연구", Journal of the Korean AcademiaIndustrial Cooperation Society, 17(2016, 6), 347-359.

(LEE, Jong-Kwan, "Halk Resminde Gösterilen On İki Çin Zodyak Hayvanının Folklor Bilinci Çalışması", Kore Akademi-Sanayi İşbirliği Derneği Dergisi, Sayı 17(2016, 6), s. 347-359.)

이현주, 신라의 건국신화와 동물 상징, 석사논문, 성균관대학교, 2004.

(LEE, Hyun-Ju, Silla'nın Kuruluş Efsanesi ve Hayvan Sembolizmi Çalışması, Yüksek Lisans Tezi, Sungkyunkwan Üniversitesi, 2004.)

일연, 삼국유사, (김원중 옮김), 민음사, 2008.

(İl Yeon, Samkukyusa(Üç Krallık Hikayesi), (ter. Kim Wonjung), Minyım Yayınevi, 2008.) 
장현주-하종경, “조선시대 직물에 나타난 동물문양의 유형과 특성”, 복식, 55(5), (2005, 8), 한국복식학회, 65-77.

(JANG, Hyen-Joo - HA, Jong-Kyung, “Joseon Hanedanlığı Kumaşlarındaki Hayvan Desen Türleri ve Özellikleri", Kore Kostüm Topluluğu Dergisi, Cilt 55, Sayı 5(2005, 8), Kore Kostüm Topluluğu, s. 65-77.)

정현학, "소에 나타난 민속학적 의미와 상징- 한국과 중국을 중심으로-“, 민속학연구, 6(1999, 11), 국립민속박물관, 457-487.

(JUNG, Yeoan-Hak, "Sığır Kavramının Folklorik Anlamı ve Sembolleri- Kore ile Çin Arasındaki Bir Karşılaştırılması-", Kore Halk Araştırmaları Dergisi, Sayı 6(1999, 11), Kore Ulusal Halk Müzesi, s. 457-487.)

축산경제신문, "세시기-올해는 경자(庚子)년 흰 쥐띠 해" (Hayvancllk Ekonomisi Gazetesi, "Bu Y1l

Beyaz Fare Yllı"), http://www.chukkyung.co.kr/news/articleView.html?idxno=56246, (Erişim tarihi, 07 Mayıs 2020).

한국민족문화대백과, "단군신화” (Kore Etnik Kültür Ansiklopedisi, "Dangun Efsanesi"), https://terms.naver.com/entry.nhn?docId=534286\&cid=46620\&categoryId=46620, (Giriş tarihi, 07, Mayıs 2020)

한국민족문화대백과, “삼국유사" (Kore Etnik Kültür Ansiklopedisi, "Samkukyusa”), https://terms.naver.com/entry.nhn?docId=2457207\&cid=46669\&categoryId=46669, (Erişim tarihi, 06 Mayis 2020)

한국민족문화대백과, “문무왕 설화” (Kore Etnik Kültür Ansiklopedisi, "Kral Munmu Efsanesi”), https://terms.naver.com/entry.nhn?docId=554634\&cid=46643\&categoryId=46643, (Erişim tarihi, 08 Mayis 2020).

한국민족문화대백과, "경주 천마총 장니 천마도" (Kore Etnik Kültür Ansiklopedisi, "Kyeongcu Çeonmaçong Cangni Çeonmado"),

https://terms.naver.com/entry.nhn?docId=563072\&cid=46657\&categoryId=46657, (Erişim tarihi, 09 Mayıs 2020).

한예민, 십이지 동물의 설화화 양상과 의미- 한국구비문학대계를 중심으로-, 석사논문, 숭실대학교, 2012.

(HAN, Yi-Min, On iki hayvan Hikayeleri ve Anlamları - Kore Sözlü Edebiyat İçerikli, Yüksek Lisans Tezi, Soongsil Üniversitesi, 2012.)

허은아, 신라의 동물형 토우에 관한 연구, 석사논문, 전남대학교, 1993.

(HU, Eun Ah, Silla'nın Hayvan Figürü Towoo Hakkında Bir Incelemesi, Yüksek Lisans Tezi, Chonnam Ulusal Üniversitesi, 1993.)

황나현, 조선시대 동물화의 상징성과 조형성에 관한 연구, 석사논문, 홍익대학교, 2012.

(HWANG Na-Hyen, Joseon Hanedanlığında Hayvancılı̆̆ın Sembolizmi ve Biçimlendirilişi Üzerine Bir Çalışma, Yüksek Lisans Tezi, Hongik Üniversitesi, 2012.)

향토문화전자대전, “쥐 이야기” (Kore Halk Kültürü Elektronik Sözlü̈̆̈̈̈, "Fare Hikayesi”), https://terms.naver.com/entry.nhn?docId=2650310\&cid=51888\&categoryId=53642, (Erişim tarihi, 08 Mayıs 2020)

BALCI, Mustafa, "Bilinmeyen Bir 12 Hayvanlı Takvim Risalesi: Takvim-i Tatar Ma'a-acem”, Türk bilgi, Say1 20(2010), s. 85-96.

BİRAY, Nergis, "12 Hayvanlı Türk Takvimi- Zaman ve İnsana Hükmetmek-, A.Ü. Türkiyat Araştırmaları Enstitüsü Dergisi, Prof. Dr. Hüseyin AYAN Özel Sayısı, Sayı 39, Erzurum 2009, s. 671-682. 
BOYRAZ, Şeref, "12 Hayvanlı Türk Takvimi ve Kehanet", Uluslararası Sosyal Araştırmalar Dergisi, Cilt 3, sayı 14(Güz 2010), s. 137-167.

DURMUŞ, İlhami, "Eski Türklerde Zaman ve Takvimler",

https://www.gunaz.tv/az/xeberler/arxiv/eski-turklerde-zaman-ve-takvimler-prof-dr-ilhamidurmus-49577, (Giriş tarihi, 07 Mayıs 2020)

KBS WORLD RADIO, “돼지 관련 속담”, (KBS WORLD RADIO, “Domuz ile İlgili Atasözü”)

http://world.kbs.co.kr/service/contents_view.htm?lang=k\&board_seq=363221,(Erişim tarihi, 09 Mayis 2020)

TAVKUL, Ufuk, "Kültürel Etkileşim Açısında On İki Hayvanlı Türk Takviminin Yayılışı", Modern Türklük Araştırmalar Dergisi, Cilt 4, sayı 1(Mart 2007), Ankara Üniversitesi, s.25-45.

TÜRKMEN, Fikret, "Türk kültüründe tarihi girişim içinde hayvan ve bitkilerin "Ölçü Birimi" olarak kullanılması hakkında", Milli Folklor, Cilt 24, Sayı 95(2012), s. 96-102.

UNAT, Yavuz, “İslâm'da ve Türklerde Zaman ve Takvim”, Türk Dünyası, Nevruz Ansiklopedisi, (ed. Öcal Oğuz), Atatürk Kültür Merkezi Başkanlığı Yayınları, Ankara 2004, s. 15-24. 